\title{
Deciphering the Role of Leptospira Surface Protein LigA in Modulating the Host Innate Immune Response
}

\section{OPEN ACCESS}

Edited by:

Junji Xing,

Houston Methodist Research Institute, United States

Reviewed by:

Jutamas Shaughnessy, University of Massachusetts Medical

School, United States Julie Cagliero,

Institut Pasteur de Nouvelle Calédonie, New Caledonia

*Correspondence: Syed M. Faisal faisal@niab.org.in

${ }^{\dagger}$ Present address: Muhammed Ashiq Thalappil,

Department of Neuroscience, Biomedicine and Movement Sciences,

University of Verona, Verona, Italy

${ }^{\ddagger}$ These authors share first authorship

Specialty section:

This article was submitted to Molecular Innate Immunity, a section of the journal

Frontiers in Immunology

Received: 02 November 2021 Accepted: 29 November 2021 Published: 16 December 2021

Citation:

Kumar A, Varma VP, Sridhar $K$, Abdullah $M$, Vyas $P$ Ashiq Thalappil M, Chang Y-F and Faisal SM (2021) Deciphering the Role of Leptospira Surface Protein LigA in Modulating the Host Innate Immune Response.

Front. Immunol. 12:807775. doi: 10.3389/fimmu.2021.807775
Ajay Kumar ${ }^{1 \neq}$, Vivek P. Varma ${ }^{1,2 \neq}$, Kavela Sridhar ${ }^{1}$, Mohd Abdullah $^{1,3}$, Pallavi Vyas ${ }^{1}$, Muhammed Ashiq Thalappil ${ }^{1 \dagger}$, Yung-Fu Chang ${ }^{4}$ and Syed M. Faisal ${ }^{1 *}$

${ }^{1}$ Laboratory of Vaccine Immunology, National Institute of Animal Biotechnology, Hyderabad, India, ${ }^{2}$ Graduate Studies, Manipal Academy of Higher Education, Manipal, India, ${ }^{3}$ Department of Biosciences, Integral University, Lucknow, India, ${ }^{4}$ Department of Population Medicine and Diagnostic Sciences, College of Veterinary Medicine, Cornell University, Ithaca, NY, United States

Leptospira, a zoonotic pathogen, is known to infect various hosts and can establish persistent infection. This remarkable ability of bacteria is attributed to its potential to modulate (activate or evade) the host immune response by exploiting its surface proteins. We have identified and characterized the domain of the variable region of Leptospira immunoglobulin-like protein $A(L A V)$ involved in immune modulation. The $11^{\text {th }}$ domain $\left(A_{11}\right)$ of the variable region of LigA ( $L A V)$ induces a strong TLR4 dependent innate response leading to subsequent induction of humoral and cellular immune responses in mice. $A_{11}$ is also involved in acquiring complement regulator $\mathrm{FH}$ and binds to host protease Plasminogen (PLG), there by mediating functional activity to escape from complementmediated killing. The deletion of $A_{11}$ domain significantly impaired TLR4 signaling and subsequent reduction in the innate and adaptive immune response. It also inhibited the binding of FH and PLG thereby mediating killing of bacteria. Our study discovered an unprecedented role of LAV as a nuclease capable of degrading Neutrophil Extracellular Traps (NETs). This nuclease activity was primarily mediated by $A_{11}$. These results highlighted the moonlighting function of LigA and demonstrated that a single domain of a surface protein is involved in modulating the host innate immune defenses, which might allow the persistence of Leptospira in different hosts for a long term without clearance.

Keywords: surface proteins, LigA, Leptospira, immune evasion, host-pathogen interaction

\section{INTRODUCTION}

Leptospirosis is one of the most widespread bacterial zoonosis, particularly in developing countries like India, and one of the major neglected infectious diseases globally (1). It is caused by the pathogenic spirochete of the genus Leptospira that can cause fatal infections involving multiple organs in human and animal hosts. According to WHO, there is a substantial economic burden of human leptospirosis with an estimated 1.03 million cases and 58,900 deaths worldwide annually (1). The actual burden may be much higher as a lot of cases are not reported due to difficulties associated with diagnosis (2). The major challenge in combating this zoonosis has been the unavailability of early diagnostics and potent vaccines that can induce cross-protection against various serovars (3). 
Understanding how Leptospira escapes from host innate immune defenses to disseminate and colonize in multiple organs for establishing infection will aid in devising prophylactic strategies.

Innate immune responses comprising of soluble factors like antimicrobial peptides and complement proteins, pattern recognition receptors like Toll-like receptors (TLRs) and NOD-like receptors (NLRs), and phagocytic cells such as Dendritic cells (DCs), neutrophils, and macrophages contribute to the killing and removal of invading pathogens by a variety of mechanisms (4). Signaling through TLRs induces activation of innate immune cells leading to secretion of pro-inflammatory cytokines (IL-6, TNF- $\alpha$ ) and expression of surface molecules (CD80, CD86, MHC-II), thereby enabling these cells to become efficient in subsequent activation of adaptive response $(5,6)$. TLRs play a key role in promoting adaptive immune responses and are also essential for T-cell expansion, differentiation, and memory formation (7). The Complement system is a vital part of innate immune defense that promptly kills the invading pathogen by opsonization and target lysis (8). To prevent damage to the host cells, the complement system is tightly regulated by soluble plasma proteins like Factor $\mathrm{H}(\mathrm{FH})$ and C4b-binding protein (C4BP) (9). $\mathrm{FH}$ and C4BP regulate the Alternative pathway (AP), Classical pathway (CP), and Lectin pathway of complement activation. Plasmin, the enzymatically active form of plasminogen (PLG) acts as a protease that potentially cleaves complement factors C3b, C4b and C5 (10). Neutrophils are major phagocytic cells that utilize a combination of reactive oxygen species (ROS), cytotoxic granules, antimicrobial peptides, and Neutrophil Extracellular Traps (NETs) to kill and degrade the invading pathogen (11). However, pathogens have devised several strategies to escape from host innate immune defenses through a mechanism mediated by their surface proteins (12). These proteins may be pro-inflammatory where they can activate APCs like macrophages and DCs but might also enable the pathogen to avoid recognition through innate receptors (TLRs) through downregulation of their expression or causing antigenic variations to evade from host defenses $(13,14)$. Pathogens escape from complement-mediated killing by expressing surface proteins that acquire complement regulators like $\mathrm{FH}$ and C4BP, act as proteases or acquire host proteases that can cleave complement components $(8,15)$. They may avoid killing by phagocytes like neutrophils by expressing surface proteins, which may help in evading extravasation and chemotaxis, preventing opsonization and phagocytosis, promoting survival inside the neutrophil, and inducing apoptosis or cell death and degrading NETs by virtue of their nuclease activity $(16,17)$.

Like other pathogens, Leptospira has also evolved strategies to modulate the host's innate immune response by exploiting the capacities of its surface proteins to favor their pathogenesis (1820). Toll-like receptors like TLR2 and TLR4 play a major role in host defense as mice lacking these receptors were highly susceptible to Leptospira infection (21). These bacteria likely modulate the expression of surface molecules (proteins, LPS) to avoid recognition through protective TLR2 and TLR4 and establish infection in the host. Several surface proteins of Leptospira have been identified as a potent activator of proinflammatory response via signaling through both TLR2 and TLR4 (22-24). Besides that, several proteins have been shown to acquire $\mathrm{FH}, \mathrm{C} 4 \mathrm{BP}$ and PLG on their surface or act as proteases to cleave complement components to evade killing (25-30). Leptospira is known to induce NET; hence it is likely that it might express surface proteins/nucleases like other bacteria to evade NETosis (31). Thus, identification and characterization of a surface protein involved in the modulation of the host innate immune response will aid in designing a better strategy to combat this bacterial zoonosis.

Leptospira immunoglobulin-like (Lig) proteins (LigA and LigB) are surface proteins having 12-13 immunoglobulin-like repeat domains similar to an invasin of Yersinia and intimin of E.coli (32). The $\mathrm{N}$ terminal region of LigA and LigB from domains 1 to 6.5 are conserved, whereas $\mathrm{C}$ terminal regions from domains 6.5 to 13 are variable $(32,33)$. Lig proteins are expressed during infection and have been shown to bind to multiple components of the host extracellular matrix (ECM), thereby mediating attachment to host cells $(34,35)$. They are the most promising vaccine candidate identified to date. Moreover, the variable region of LigA (LAV) comprising domain 6.5-13 (LAV) was shown to be sufficient to induce protection against challenge in the hamster model (36-41). Despite various reports confirming the protective role of LAV, its involvement in the modulation of the host innate immune response has not been studied extensively. Several groups demonstrated that Lig proteins bind to $\mathrm{FH}$ and $\mathrm{C} 4 \mathrm{BP}$ to inhibit lectin, classical and alternative pathways; however, specific domains involved in binding to these regulators have not been characterized $(26,27$, $29,42,43)$. Further, the role of the protein in activation of the innate response or evasion from killing by phagocytes has not been reported so far. In the present study, we have demonstrated the role of LAV in modulating the host innate immune response. Using various assays, we identified the domain/s involved in activating of innate and subsequent adaptive immune response and evasion from complement-mediated killing via binding to FH and host protease PLG. Further, we demonstrated LAV's nuclease activity, which might play a major role in evasion from Neutrophil extracellular traps (NETosis).

\section{RESULTS}

\section{LAV Induced TLR4 Dependent Activation of Mouse Macrophages}

To test whether the immunogenicity of Variable region of LigA (LAV) correlates to innate immune response activation, we tested its ability to activate mouse macrophages. We cloned, expressed, and purified LAV in a soluble form (Supplementary Figure 1). We stimulated mouse macrophages with varying doses $(1,2$, and $5 \mu \mathrm{g} / \mathrm{ml})$ of the protein, and our result shows that LAV induced production of pro-inflammatory cytokines (IL-6, TNF- $\alpha$ ) in a dose-dependent manner (Figure 1A). Taking into account that the purified protein might have LPS 


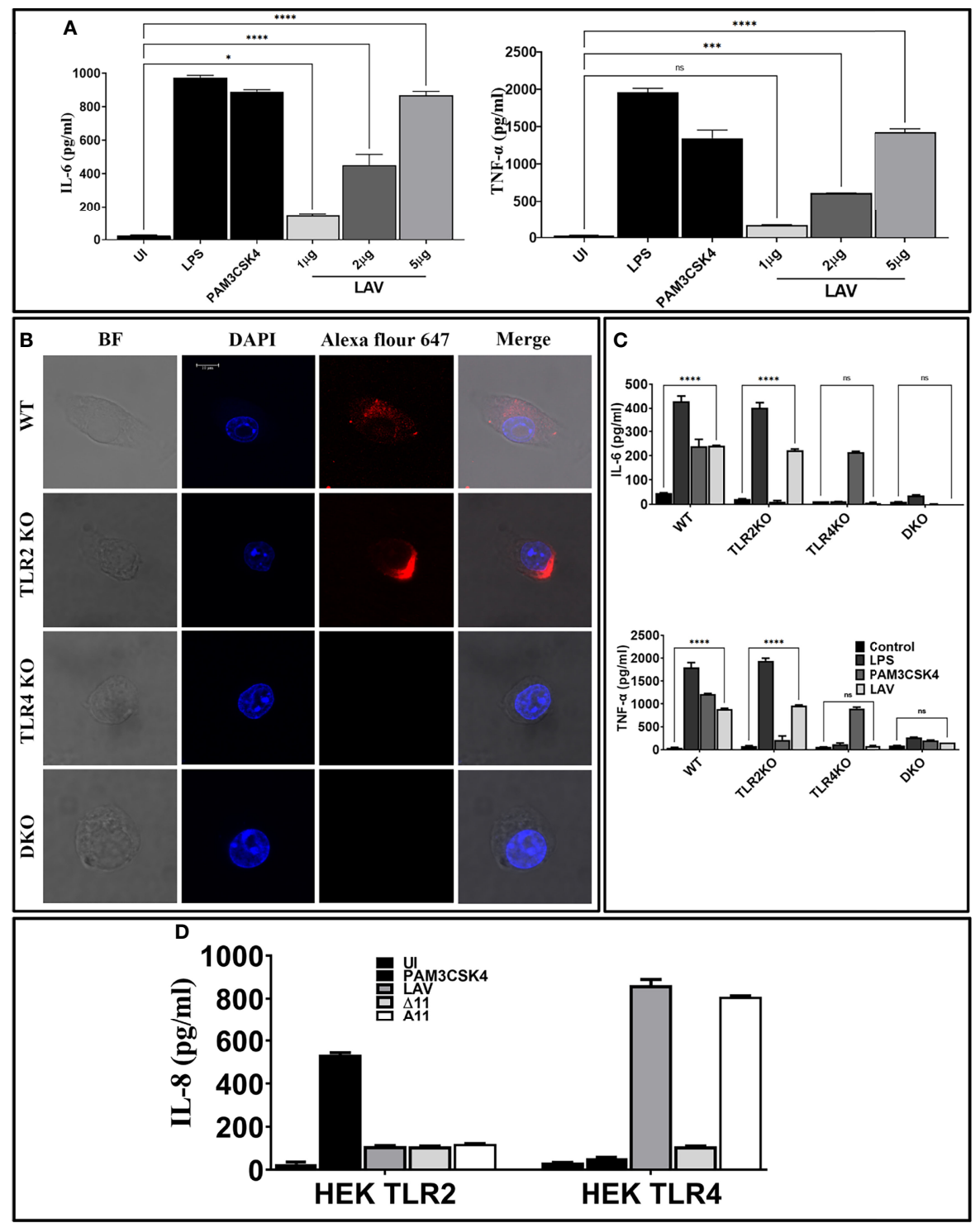

FIGURE 1 | Variable region of LigA (LAV) induced TLR4 dependent activation of mouse macrophages. (A) Screening of pro-inflammatory response of LAV in RAW264.7 cells. RAW264.7 cell lines were stimulated with LAV in varying concentrations 1 or 2 or $5 \mu \mathrm{g} / \mathrm{ml}$ along with PMB for $24 \mathrm{~h}$ and supernatant was collected to measure levels of TNF- $\alpha$ and IL-6 cytokines by using ELISA. (B) Binding of LAV with TLR4. WT, TLR2KO, TLR4KO, or DKO macrophages were incubated with LAV $(2 \mu \mathrm{g} / \mathrm{ml})$ for $30 \mathrm{~min}$. After washing, cells were fixed and stained with then stained with Alexa Flour 647 conjugated rabbit anti-mouse IgG and analysed by the confocal microscope as described in materials and methods. (C) Pro-inflammatory response of mouse macrophages stimulated with rLig proteins with LAV. WT, TLR2KO, TLR4KO and DKO macrophages cell lines were treated LAV at $2 \mu \mathrm{g} / \mathrm{ml}$ for $24 \mathrm{~h}$ at $37^{\circ} \mathrm{C}$ in presence of $5 \% \mathrm{CO}{ }_{2}$ and levels of IL- 6 and TNF- $\alpha$ in the supernatants were measured by ELISA. (D) IL-8 response in HEK293-TLR4 cells stimulated with LAV. HEK293T cells transfected with TLR2, TLR4 and NF-kB reporter plasmids were stimulated with LAV $(2 \mu \mathrm{g} / \mathrm{ml})$ for $24 \mathrm{~h}$ and IL-8 was measured in the culture supernatant by ELISA. E. coli LPS (500ng/ml) or PAM3CSK4 $(20 \mathrm{ng} / \mathrm{ml})$ as TLR4 and TLR2 ligands respectively were used as positive controls in all experiments wherever indicated. Data are representative of three different experiments. Significant differences were calculated using the one or two way ANOVA ( ${ }^{\star \star \star *}{ }^{* \star *}{ }^{*}{ }^{*}$, ns indicates $\mathrm{P}<0.0001,<0.001, \mathrm{P}<0.05$ and nonsignificant respectively).

contamination, they were pre-treated twice with PMB to remove the endotoxin activity. 500ng/ml LPS pre-incubated with the same concentrations of Polymyxin-B Agarose was used as control. The concentration of LPS in final protein preparation varied from $(0.10-0.15 \mathrm{ng} / \mathrm{ml})$. The effect was protein-specific because Proteinase- $K$ plus heating abolished cytokine production (Supplementary Figure 2). Besides, PMB inhibited the LPS induced cytokine production but did not attenuate the levels induced by LAV, indicating that the stimulatory effects observed were specific to protein and not due to contamination with LPS (Supplementary Figure 2). Next, we tested whether this LAV-induced activation was via signaling through TLR2 or TLR4. As confirmed by confocal microscopy, LAV showed binding, specifically with TLR4 and failed to bind to the TLR2 
receptor (Figure 1B). To verify that this binding leads to activation and subsequent cytokine production, we stimulated WT, TLR2KO, TLR4KO and DKO macrophages and HEK-293T cells expressing these receptors with LAV. Our result shows that while WT and TLR2KO macrophages cells induced significant levels of IL- 6 and TNF- $\alpha$, TLR4KO and DKO macrophages failed to induce these cytokines (Figure 1C). Similarly, HEKTLR4 stimulated with LAV produced significant levels of IL-8, whereas HEK-TLR2 cells didn't produce a significant level of this cytokine (Figure 1D). These results indicate that LAV is a TLR4 ligand that induces signalling through this receptor for the production of pro-inflammatory cytokines.

\section{$11^{\text {th }}$ Domain of the Variable Region of LigA $\left(A_{11}\right)$ Is Involved in Signalling Through TLR4 for the Activation and Maturation of Macrophages}

Since LAV induced TLR4-dependent activation of mouse macrophages, we aimed to identify and characterize the domain/s involved in activation. We cloned, expressed and purified the individual domain $\left(\mathrm{A}_{8}-\mathrm{A}_{13}\right)$ and tested their ability to activate mouse macrophages (RAW264.7 cells). Our result shows that only $11^{\text {th }}$ domain $\left(\mathrm{A}_{11}\right)$ induced a significant level of IL-6 and TNF- $\alpha$ (Figure 2A). To confirm that $A_{11}$ is involved in the production of cytokines, we created domain deletion mutants of $\operatorname{LAV}\left(\mathrm{A} \Delta_{8}-\mathrm{A} \Delta_{13}\right)$ and purified the proteins in the soluble form (Supplementary Figure 1B). We tested the ability of these mutants to activate mouse macrophages, and our result shows that all the deletion mutants of LAV induced production of IL-6 and TNF- $\alpha$ except $A \Delta_{11}$, further confirming that this domain is involved in the activation of macrophages and subsequent production of cytokines (Figure 2B). We tested its binding with the receptor to confirm that $A_{11}$ is involved in interaction and subsequent signaling via TLR4. Confocal microscopy confirmed the binding of $\mathrm{A}_{11}$ with the mouse TLR4 as strong anti- $A_{11}$ fluorescence was observed on the surface of WT and TLR2KO cells but little fluorescence on TLR4KO or DKO cells. Further, there was very little anti-A $\Delta_{11}$ fluorescence on the surface of all cell types indicating that this protein failed to bind to the TLR receptor (Figure 2C). To confirm that this TLR4 binding leads to activation of these cells, we stimulated mouse WT, TLR2KO, TLR4KO, and DKO macrophages with LAV, $\mathrm{A}_{11}$, and $A \Delta_{11}$, and our results indicate that $A_{11}$ induced IL- 6 and TNF- $\alpha$ production via signaling through TLR4 as TLR4KO and DKO macrophages failed to induce any significant level of these cytokines. Further, the inability of $\mathrm{A} \Delta_{11}$ to induce substantial levels of cytokines in WT or TLR2 KO macrophages indicates that the $11^{\text {th }}$ domain is critical for signaling via TLR4 (Figure 2D). To confirm whether stimulation with $\mathrm{A}_{11}$ causes macrophage activation and maturation, we analyzed the expression of costimulatory molecules (CD80, CD86, and CD40) and the maturation marker (MHC-II) in RAW264.7 cells. Our Flow cytometry results show that LAV and $\mathrm{A}_{11}$ significantly upregulated the expression of CD80, CD86, CD40, and MHCII, whereas $\mathrm{A} \Delta_{11}$ induced significantly lower level of expression of CD80, CD40 and MHCII and failed to upregulate
CD86, indicating that $A_{11}$ is primarily involved in upregulating the expression of these surface molecules (Figure 2E). To understand whether deletion of the $11^{\text {th }}$ domain leads to structural changes in the protein, which might be contributing to impairing its innate immune activity, we did CD spectroscopy and our result shows that deletion of $\mathrm{A}_{11}$ has reduced the helix and beta sheets and, in turn, distorted the structure but didn't have any effect on proper folding of LAV (Supplementary Figure 3). In conclusion, our results demonstrate that $A_{11}$ is involved in TLR4 dependent activation and maturation of mouse macrophages.

\section{$A_{11}$ Induces Immune Activation via MAPK Signaling Involving the MyD88 Adapter}

Since TLR4 involves both MyD88 and TRIF adapter for downstream signaling and $\mathrm{A}_{11}$ induced immune activation through TLR4, we examined the adapter molecule involved in the signaling. We stimulated MyD88KO, TRIFKO, and TMDKO macrophages with $A_{11}$, and our results show that the signaling pathway involves MyD88 adapter as MyD88KO macrophages failed to induce significant levels of IL- 6 and TNF- $\alpha$. In contrast, TRIFKO macrophages induced significant IL- 6 and TNF-a although the levels of the cytokines were lower than WT macrophages indicating that there could be involvement of TRIF adapter in signalling (Figure 3A). Because MAP Kinases are critical factors involved in cellular responses to inflammatory stimuli, we examined the activation of this pathway in response to $\mathrm{A}_{11}$. We stimulated mouse WT, TLR2KO, TLR4KO, and DKO macrophages with $\mathrm{A}_{11}$ and analyzed the phosphorylation of P38, JNK, ERK and degradation of IkB $\alpha$. Our results shows that there was strong phosphorylation of p38 and JNK in WT and TLR2 macrophages whereas it was significantly reduced in TLR4 and DKO macrophages indicating that $\mathrm{A}_{11}$ is signalling via TLR4 using p38 and JNK pathway to produce proinflammatory cytokines (Figure 3B). Next, to elucidate the functional role of these kinases in $A_{11}$ induced macrophage activation and maturation, we used pharmacological inhibitors of these pathways and analyzed cytokines in RAW264.7 cells pre-treated with or without inhibitors of NF-kB, JNK, p-38 or ERK. IL-6 and TNF- $\alpha$ production was significantly blocked by $\mathrm{p} 38$ inhibitor $(\mathrm{P}$ $<0.05,50 \%$ inhibition with $2 \mu \mathrm{g} / \mathrm{ml} \mathrm{A}_{11}$ ) and by JNK and NF-kB $\left(\mathrm{P},<0.05,30 \%\right.$ inhibition with $\left.2 \mu \mathrm{g} / \mathrm{ml} \mathrm{A}_{11}\right)$. ERK inhibitor didn't affect the production of cytokine, indicating that this pathway is not involved in signalling. The production of TNF- $\alpha$ was also significantly blocked by JNK, $\mathrm{p}-38$, and NF- $\mathrm{\kappa B}$ inhibitor $(\mathrm{P}<0.05$, $60 \%$ inhibition). A combination of all inhibitors completely inhibited $A_{11}$ induced cytokine production (Figure 3C). All these results suggest that $A_{11}$ stimulates the production of proinflammatory cytokines through $\mathrm{p} 38$, JNK and NF-kB pathways. The ability of $\mathrm{A}_{11}$ to regulate innate responses was further investigated based on the expression of key inflammatory cytokine and chemokine genes at various time points $(4,24$, and $48 \mathrm{~h}$ ). WT, TLR2KO, TLR4KO and DKO mouse macrophage were stimulated with $A_{11}$, and expression of mRNA transcript was analyzed by RT-PCR. $A_{11}$ induced CXCL10, IL-1 $\beta$, TNF- $\alpha$, COX2, iNOS, MCP-1, and IL-6 in WT and TLR2KO mouse 

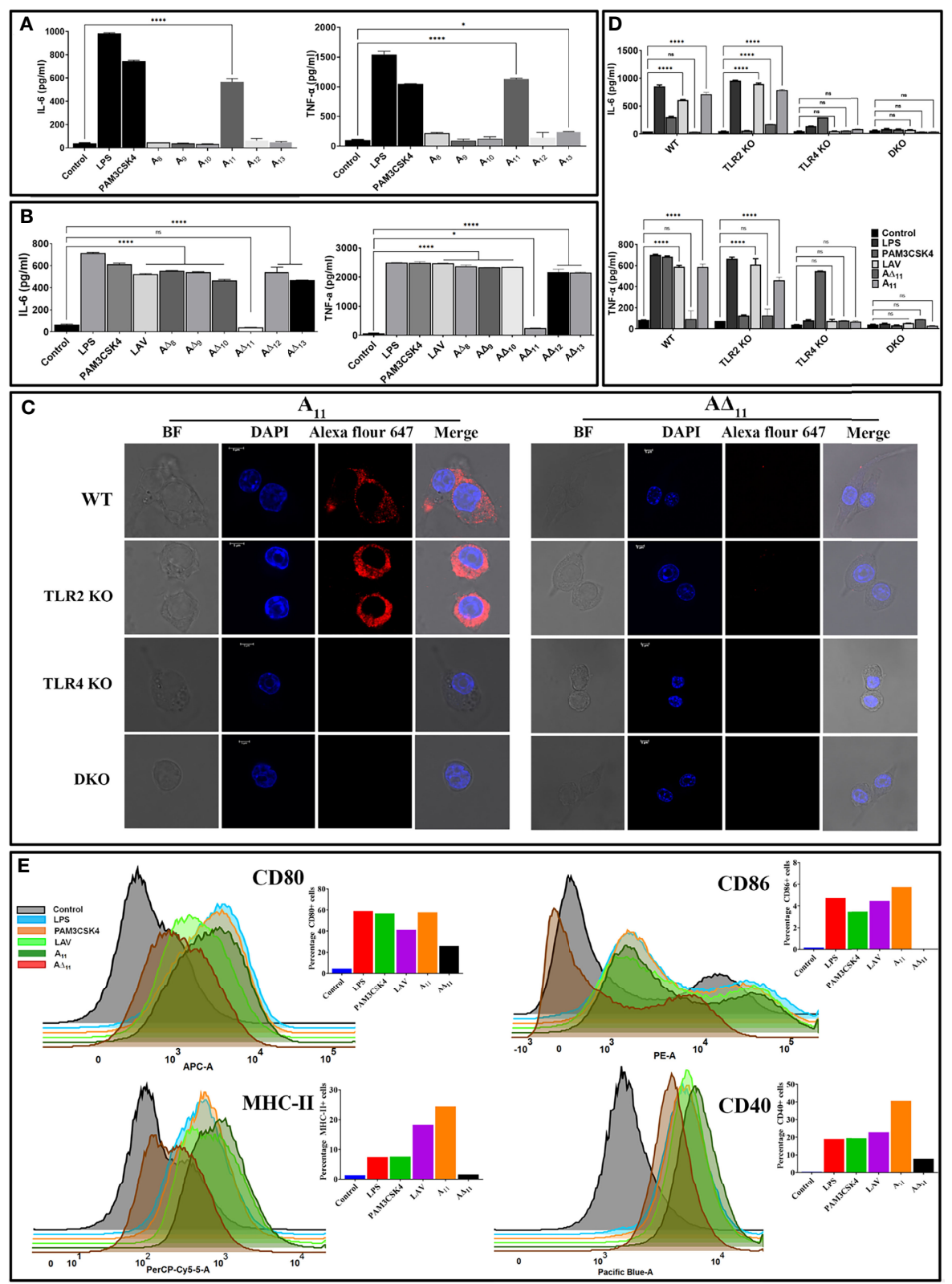

FIGURE $2 \mid 11^{\text {th }}$ domain of LigA $\left(A_{11}\right)$ is involved in binding to TLR4 and subsequent signalling leading to activation and maturation of mouse macrophages. (A) Screening of pro-inflammatory response of individual domains of LAV in RAW264.7 cells. RAW264.7 cells were incubated with individual domains $\left(\mathrm{A}_{8}\right.$ - $\mathrm{A}_{13}$ ) at concentration of $2 \mu \mathrm{g} / \mathrm{ml}$ pre-treated with PMB for $24 \mathrm{~h}$ at $37^{\circ} \mathrm{C}$ in presence of $5 \% \mathrm{CO}_{2}$ and supernatant was collected to measure levels of IL- 6 and TNF- $\alpha$ by ELISA. (B) Screening of pro-inflammatory response of domain deletion mutants of LAV in RAW264.7 cells. RAW264.7 cells were stimulated with LAV or corresponding deletion mutants $\left(\mathrm{A} \triangle_{8}-\mathrm{A} \triangle_{13}\right)$ at a concentration of $2 \mu \mathrm{g} / \mathrm{ml}$ pre-treated with $\mathrm{PMB}$ for $24 \mathrm{~h}$ at $37^{\circ} \mathrm{C}$ in the presence of $5 \% \mathrm{CO} 2$ and supernatant was collected to measure levels of IL-6 and TNF- $\alpha$ by ELISA. (C) Binding of $A_{11}$ with the mouse TLR4. WT, TLR2KO, TLR4KO or DKO macrophages cell lines were incubated with $A_{11}$ and $A_{\Delta 11}(2 \mu \mathrm{g} / \mathrm{ml})$ for $30 \mathrm{~min}$. After washing, cells were fixed and stained with respective antibodies and analysed by confocal microscope as described in materials and methods. (D) The pro-inflammatory response of mouse macrophages stimulated with $A_{11}$. WT, TLR2KO, TLR4KO and DKO bone marrow-derived macrophages cell lines were treated with LAV, $\mathrm{A}_{11}, \mathrm{~A} \triangle_{11}(2 \mu \mathrm{g} / \mathrm{ml})$, LPS $(500 \mathrm{ng} / \mathrm{ml})$ or PAM3CSK4(20ng/ml) for $24 \mathrm{~h}$ at $37^{\circ} \mathrm{C}$ in presence of $5 \% \mathrm{CO} 2$ and levels of IL-6 and TNF- $\alpha$ in the supernatants were measured with ELISA. (E) $A_{11}$ enhanced the expression of surface markers in mouse macrophages. RAW264.7 cells were incubated with LPS $(500 \mathrm{ng} / \mathrm{ml})$ or PAM3CSK $(20 \mathrm{ng} / \mathrm{ml})$ or LAV or $\mathrm{A}_{11}$ or $\mathrm{A} \triangle_{11}(2 \mu \mathrm{g} / \mathrm{ml})$ for $24 \mathrm{~h}$ at $37^{\circ} \mathrm{C}$ in presence of $5 \% \mathrm{CO}$. Cells were stained with fluorochrome-conjugated antibodies and then analyzed by Flow cytometry as described in materials and methods. Control indicates uninduced or unstimulated cells, E. coli LPS $(500 \mathrm{ng} / \mathrm{ml})$ or PAM3CSK4 $(20 \mathrm{ng} / \mathrm{ml})$ as TLR4 and TLR2 ligands respectively were used as positive controls in all experiments wherever indicated. Data are representative of three different experiments. Significant differences were calculated using the one or two way ANOVA ( ${ }^{\star \star \star \star},{ }^{\star}$, ns indicates $\mathrm{P}<0.0001, \mathrm{P}<0.05$ and non-significant respectively). 

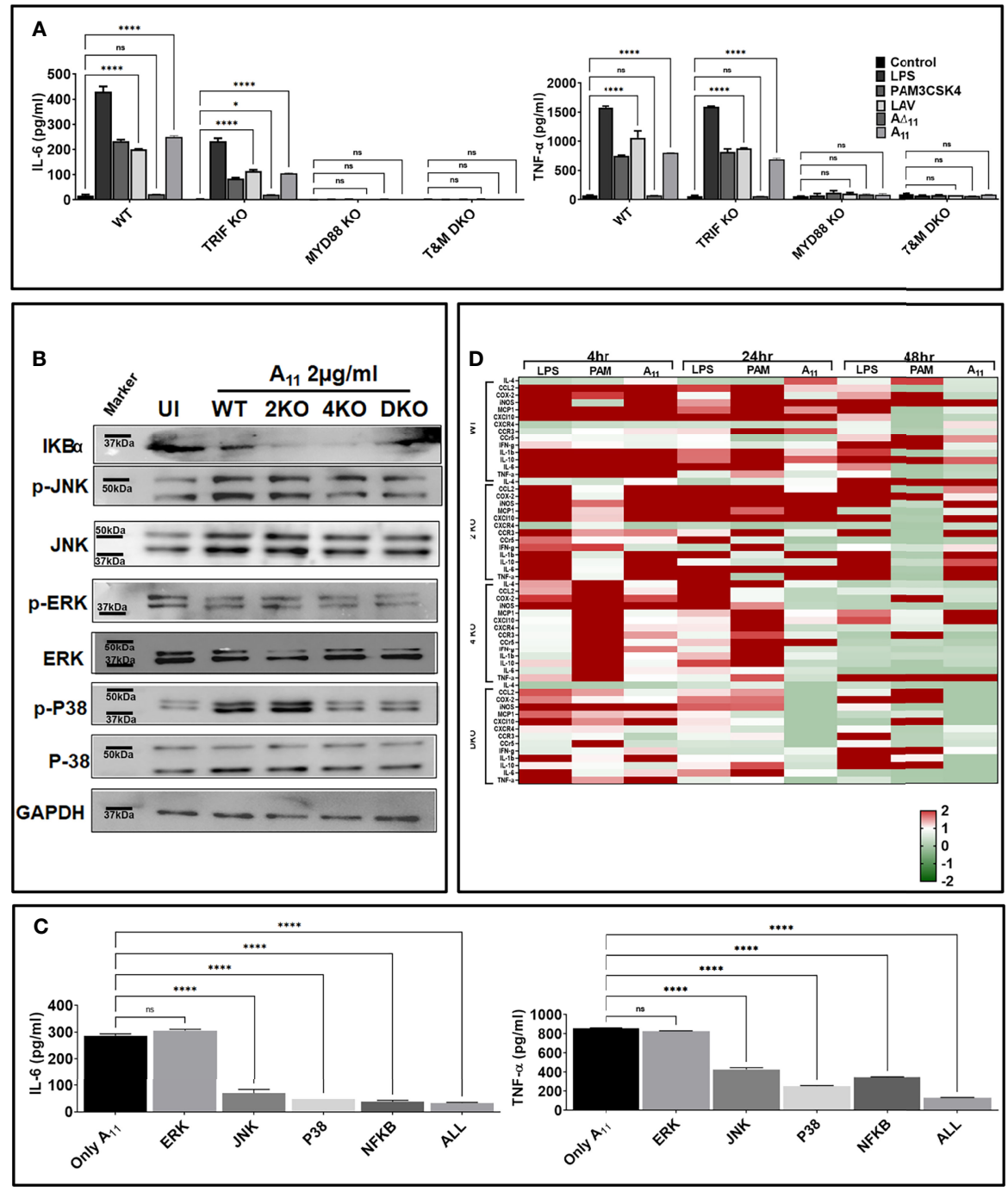

FIGURE $3 \mid 11^{\text {th }}$ domain of LigA $\left(\mathrm{A}_{11}\right)$ produces pro-inflammatory cytokines via signalling through MAP kinase involving p38 and JNK pathway. (A) $A_{11}$ signals through TLR4 involving the MyD88 adapter. WT, MyD88 KO, TRIF KO and TMDKO bone marrow-derived macrophages cell lines were treated with LAV or $\mathrm{A}_{11}$ or $\mathrm{A} \triangle_{11}(2 \mu \mathrm{g} / \mathrm{ml})$ for $24 \mathrm{~h}$ at $37^{\circ} \mathrm{C}$ in the presence of $5 \% \mathrm{CO}_{2}$ and levels of IL-6 and TNF- $\alpha$ in the supernatants were measured by ELISA. (B) $A_{11}$ signals through TLR4 via the MAP kinase pathway involving p38 and NFkb. WT or TLR2KO or TLR4KO or DKO macrophages cell lines were stimulated with $\mathrm{A}_{11}(2 \mu \mathrm{g} / \mathrm{ml})$ for $24 \mathrm{~h}$ at $37^{\circ} \mathrm{C}$ in the presence of $5 \% \mathrm{CO}_{2}$. Levels of phosphorylated p38, JNK, and ERK $1 / 2$ induced by $\mathrm{A}_{11}$ were analyzed by western blot as described in materials and methods. (C) Pharmacological inhibitors of p38 and NFkb significantly reduces $A_{11}$ mediated cytokine response. RAW 264.7 cells were pre-treated for 30min with NF-kB

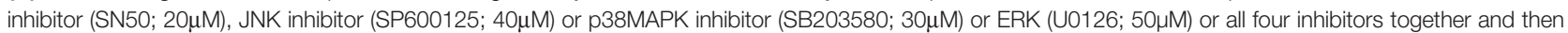
stimulated with $\mathrm{A}_{11}(2 \mu \mathrm{g} / \mathrm{ml})$ for $24 \mathrm{~h}$ at $37^{\circ} \mathrm{C}$ in the presence of $5 \% \mathrm{CO}_{2}$ and supernatant was collected to measure levels of IL-6 and TNF- $\alpha$ by ELISA. (D) Analysis of expression of immune response-related genes in mouse macrophages stimulated with $A_{11}$. WT, TLR2KO, TLR4KO and DKO mouse macrophage cell lines were treated with $2 \mu \mathrm{g} / \mathrm{ml} \mathrm{A}_{11}$ for $4 \mathrm{~h}$ or $24 \mathrm{~h}$ or $48 \mathrm{~h}$. Cells were recovered, RNA was isolated, converted to cDNA and gene expression was analyzed by RT-PCR as described in material and methods. The data were presented as fold changes between stimulated cells vs control and normalized to GAPDH. E. coli LPS (500ng/ml) or PAM3CSK4 $(20 \mathrm{ng} / \mathrm{ml})$ as TLR4 and TLR2 ligands respectively were used as positive controls in all experiments wherever indicated. All data are representative of

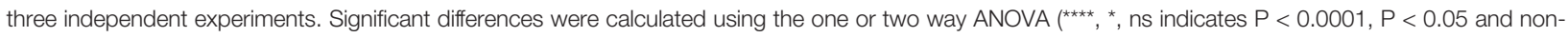
significant respectively).

macrophage at $4 \mathrm{~h}$ and $24 \mathrm{~h}$ time point which was significantly reduced or down-regulated in TLR4KO and DKO macrophages (Figure 3D). PAM3CSK4 (TLR2 ligand) and LPS (TLR4 ligand) showed significant upregulation of genes involved in TLR2 and TLR4 signalling as expected. These results demonstrate that $A_{11}$ induced TLR4 dependent expression of innate response genes.

\section{$A_{11}$ Is an Immuno-Dominant Domain That Induces a Strong Adaptive Immune Response}

To test whether the innate response induced by $\mathrm{A}_{11}$ correlates to subsequent induction of adaptive response, we evaluated antigen-specific humoral, and cell-mediated immune response 
in mice immunized with LAV and $A_{11}$ in alum adjuvant. Our results show that mice immunized with $A_{11}$ with or without alum adjuvant-induced strong antibody response at day 28 postimmunization (Figure 4A). The generation of high levels of IgG1 and significant levels of IgG2c against $A_{11}$, indicates a mixed Th1 and Th2 response (Figure 4A). $A_{11}$ failed to induce a significant level of IgA. $\mathrm{A}_{11}$ induced proliferation generation of $\mathrm{T}$ cells secreting significant levels of IL-4 and IL-10 (Th2 cytokines) and high levels of IFN- $\gamma$ (Th1 cytokine) (Figures 4B, C). There was no significant enhancement in antibody levels against $A_{11}$ with the addition of alum adjuvant; however, cells obtained from Alum- $A_{11}$ immunized animals produced higher levels of IL-10 and IFN- $\gamma$ (Figures $\mathbf{4 A - C}$ ). To test whether $\mathrm{A}_{11}$ is an immunodominant domain, we analysed IgG response at day 28 in animals immunized with LAV or $\mathrm{A}_{11}$ or $\mathrm{A} \Delta_{11}$ in Freund's adjuvant. Our results show that $\mathrm{A} \Delta_{11}$ immunized animals induced significantly lower levels of IgG than those immunized with LAVor $\mathrm{A}_{11}$ (Figure 4D). This result correlated to a significant decrease in levels of IgG, cell proliferation, and induction of cytokines when serum and lymphocytes isolated from LAV-Alum immunized animals were used to analyze the response against $\mathrm{A} \Delta_{11}($ Figures $\mathbf{4 E}-\mathbf{G})$. Altogether, these results indicate that $A_{11}$ is an immuno-dominant domain, and its deletion significantly impairs the ability of LAV to induce a robust adaptive immune response.

\section{Leptospira Evades Complement-Mediated Killing by Acquiring Complement Regulators Through $\mathrm{A}_{11}$}

Leptospira evades complement-mediated killing by acquiring complement regulators ( $\mathrm{FH}$ and $\mathrm{C} 4 \mathrm{BP}$ ) or host proteases (PLG) which involves binding with surface proteins. Lig proteins, including LigA have been shown to bind to $\mathrm{FH}$, C4BP and PLG. However, except for C4BP the domain/s of LigA involved in binding to FH or PLG have not been characterized. To identify and characterize the domain of LAV involved in binding to FH and PLG, we screened the individual domains $\left(\mathrm{A}_{8}-\mathrm{A}_{13}\right)$ and corresponding deletion mutants $\left(\mathrm{A} \Delta_{8^{-}}\right.$ $\mathrm{A} \Delta_{13}$ ) for their ability to bind with FH and PLG. Our dot blot result shows that only $A_{11}$ and all the deletion mutants except $\mathrm{A} \Delta_{11}$ were able to bind to FH and PLG (Figure 5A). This binding was further confirmed by pulldown assay and ELISA, and our result shows that while $A_{11}$ led to strong binding, $\mathrm{A} \Delta_{11}$ failed to bind to both $\mathrm{FH}$ and PLG (Figures 5B, C). We further determined if the binding of $\mathrm{A}_{11}$ with $\mathrm{FH}$ is sufficient for its functional activity. Our result shows that both LAV and $A_{11}$ were able to bind to $\mathrm{FH}$ to cleave $\mathrm{C} 3 \mathrm{~b}$ in the presence of Factor I (FI) as evidenced by cleavage fragments. In contrast, $\mathrm{A} \Delta_{11}$ failed to do so, indicating that the $11^{\text {th }}$ domain is involved in binding with and mediating the cofactor activity (Figure 5D). Our ELISA result shows that $A_{11}$ binds with PLG and converts it into active plasmin, whereas $\mathrm{A} \Delta_{11}$ failed to generate a significant level of plasmin (Figure 5E). Western blot analysis further confirms that the released plasmin was able to cleave $\mathrm{C} 3 \mathrm{~b}$ in presence of $\mathrm{A}_{11}$ whereas failed to do so in presence of $\mathrm{A} \Delta_{11}$ indicating that $11^{\text {th }}$ domain is involved in PLG binding and mediating subsequent plasmin activity (Figure 5E). To establish the role of $A_{11}$ in the complement-mediated killing, we incubated E. coli with $10 \%$ Normal Human Serum (NHS) pre-incubated with $A_{11}$ or LAV or $\mathrm{A} \Delta_{11}$. Our results show that both LAV and $\mathrm{A}_{11}$ domains could rescue bacteria from complement-mediated killing, but $\mathrm{A} \Delta_{11}$ failed to do so, indicating that the $11^{\text {th }}$ domain is involved in evasion from complement-mediated killing (Figure $\mathbf{5 F}$ and Supplementary Figure 3).

\section{LAV Is a Nuclease Involved in the Evasion of Leptospira From Neutrophil Extracellular Traps}

Recently, it has been shown that Leptospira induces NET; however, a protein with nuclease activity to degrade NET has not been reported. To test whether LAV has nuclease activity, which might have a role in evasion from NETs, we incubated plasmid or linear DNA with varying concentrations of the protein ( 1 to $10 \mu \mathrm{g})$, and our result shows that LAV was able to degrade both plasmid and linear DNA in a dose-dependent manner indicating that its having both endo and exonuclease activity (Figures 6A, B). To analyze if this activity is restricted to any domain, we incubated the linear DNA with individual domains $\left(\mathrm{A}_{8}-\mathrm{A}_{13}\right)$ or deletion mutants $\left(\mathrm{A} \Delta_{8}-\mathrm{A} \Delta_{13}\right)$ and our result shows that $A_{11}$ and $A_{13}$ were able to degrade DNA whereas all the deletion mutants except $\mathrm{A} \Delta_{11}$ degraded DNA with equal propensity (Figures 6C, D). Further, $\mathrm{A} \Delta_{11}$ was also not able to cause significant degradation of plasmid DNA (Figure 6E). These results indicate that LAV's nuclease activity primarily resides in $11^{\text {th }}$ domain, and LAV is mediating this activity by utilizing this domain. To test whether LAV can cleave the Neutrophil Extracellular Trap (NET) we stimulated the mouse neutrophils with phorbol 12-myristate 13-acetate (PMA) to induce NET and then treated them with LAV $(5 \mu \mathrm{g} /$ $\mathrm{ml})$. Our confocal microscopy result shows that LAV could degrade the PMA induced NET, further confirming its nuclease activity and possible role in degrading NETs in vivo (Figure 6F). These results indicate that LAV has nuclease activity that Leptospira might exploit to evade from NETosis.

\section{DISCUSSION}

The ability of Leptospira to cause persistent infection and efficient colonization in a variety of hosts reflects its potential to subvert or thwart the innate immune response (15). This ability has been attributed to the procession of a wide variety of surface molecules like proteins, lipopolysaccharide, etc., which are redundant in their function and may also undergo structural variation to avoid recognition by the host immune system been observed in other spirochetes (12). Surface proteins, including lipoproteins from spirochetes like Borrelia and Treponema play a critical role in immune evasion by limiting their expression or inducing antigenic variation after infection, which greatly enhances host infectivity and persistence (13, 14, 44). Leptospira, like other pathogens, may voluntarily interact with TLRs (or other innate receptors) through surface molecules 


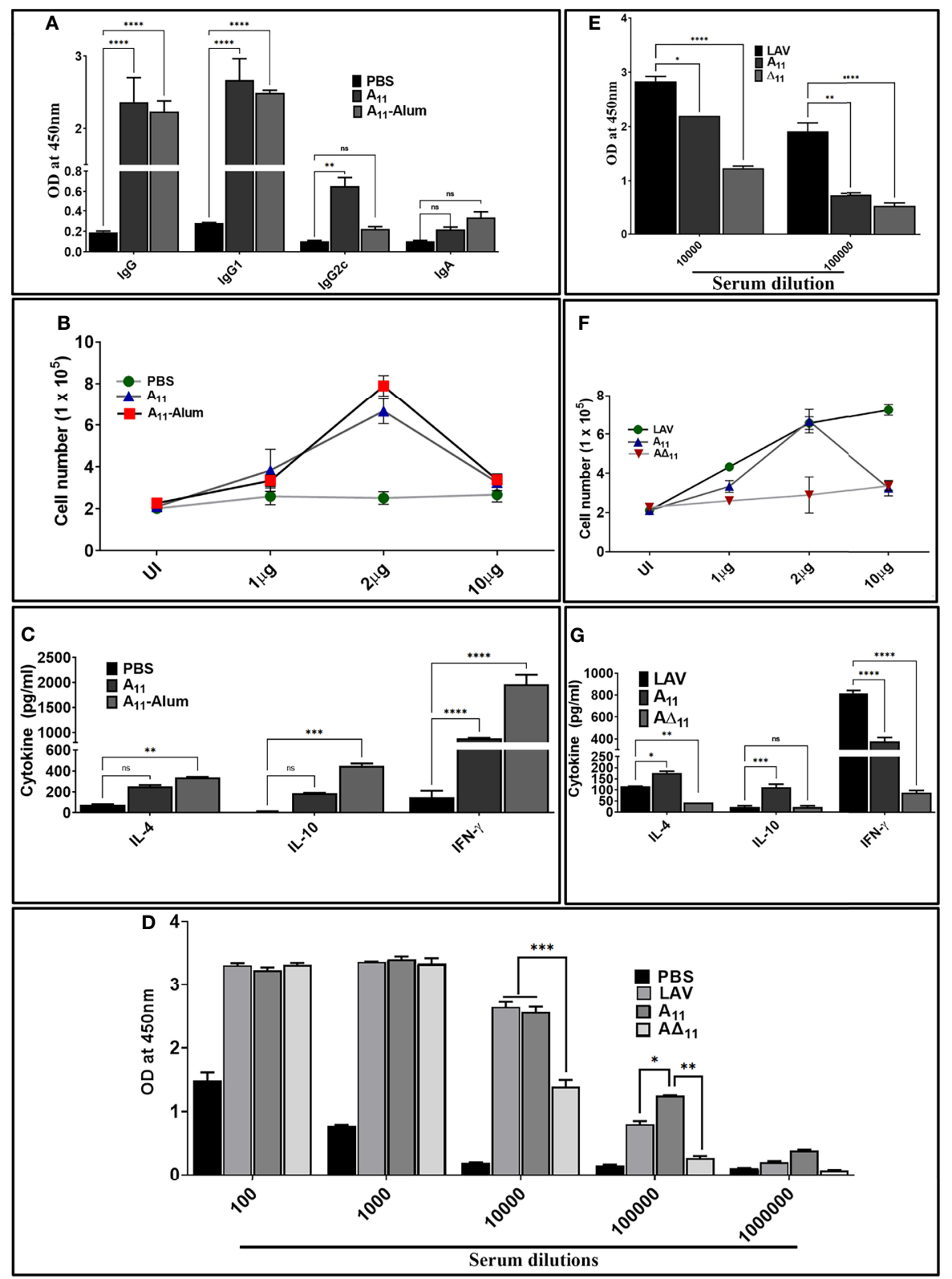

FIGURE $4 \mid A_{11}$ is an immuno-dominant domain that induces robust antibody and T cell response in mice. (A) Antibody response. The antibody response (Total $\lg G$, IgG1, IgG2C and IgA) on day 28 in various immunized groups (PBS, $A_{11}, A_{11}$-Alum) was evaluated by ELISA as described in materials and methods. (B) Lymphocyte proliferation. The proliferation of splenocytes isolated from various groups was analyzed by stimulating with recall antigen $\left(A_{11}\right)$ and counting cells after 72h. (C) Cytokine analysis. Culture supernatant from spleenocytes stimulated with $\mathrm{A}_{11}$ for $72 \mathrm{~h}$ were analyzed for IL-4, IL-10 and IFN- $\gamma$ by using a sandwich ELISA kit following manufacturer's instructions. (D) Total IgG response at day 28 in animals immunized with LAV, $A_{11}$, and $A \triangle_{11}$ in Fruend's adjuvant. Total IgG at day 28 was analysed in serum from animals immunized LAV, $A_{11}$ and $A \triangle_{11}$ in Fruend's adjuvant by ELISA as described above. (E) Antibody response against $A_{11}$ and $A \triangle_{11}$ in serum of animals immunized with LAV-Alum. Total IgG was analyzed in serum from LAV immunized animals (diluted at 1:10000 and 1:100000) against $A_{11}$ and $A \triangle_{11}$ by ELISA as described above (F) Cell proliferation and (G) Cytokine analysis of lymphocytes isolated from LAV-Alum immunized animals after in-vitro stimulation with $A_{11}$ and $A \Delta_{11}$. Lymphocytes isolated at day 28 from animals immunized with LAV-Alum were stimulated with $A_{11}$ and $A \triangle_{11}$ for $72 \mathrm{~h}$ and analysed for proliferation and cytokines in the culture supernatant were determined as described above. All data are representative of three independent experiments. Significant differences were calculated using the one or two way ANOVA $\left({ }^{* * * *},{ }^{* * *},{ }^{* *},{ }^{*}\right.$, ns indicates $\mathrm{P}<0.0001, \mathrm{P}<0.01, \mathrm{P}<0.01, \mathrm{P}<0.05$ and non-significant respectively).

(proteins, LPS) but might evade this recognition through multiple mechanisms to establish infection or fitness in the host (45-47). Both TLR2 and TLR4 receptors play a major role in host defense against Leptospira infection (21). It has been shown that TLR4 plays a critical role in controlling bacterial load and developing severe leptospirosis in mice (48). Thus, it is likely that those surface proteins and LPS which are natural ligand of these receptors and can activate macrophages and DCs, might 

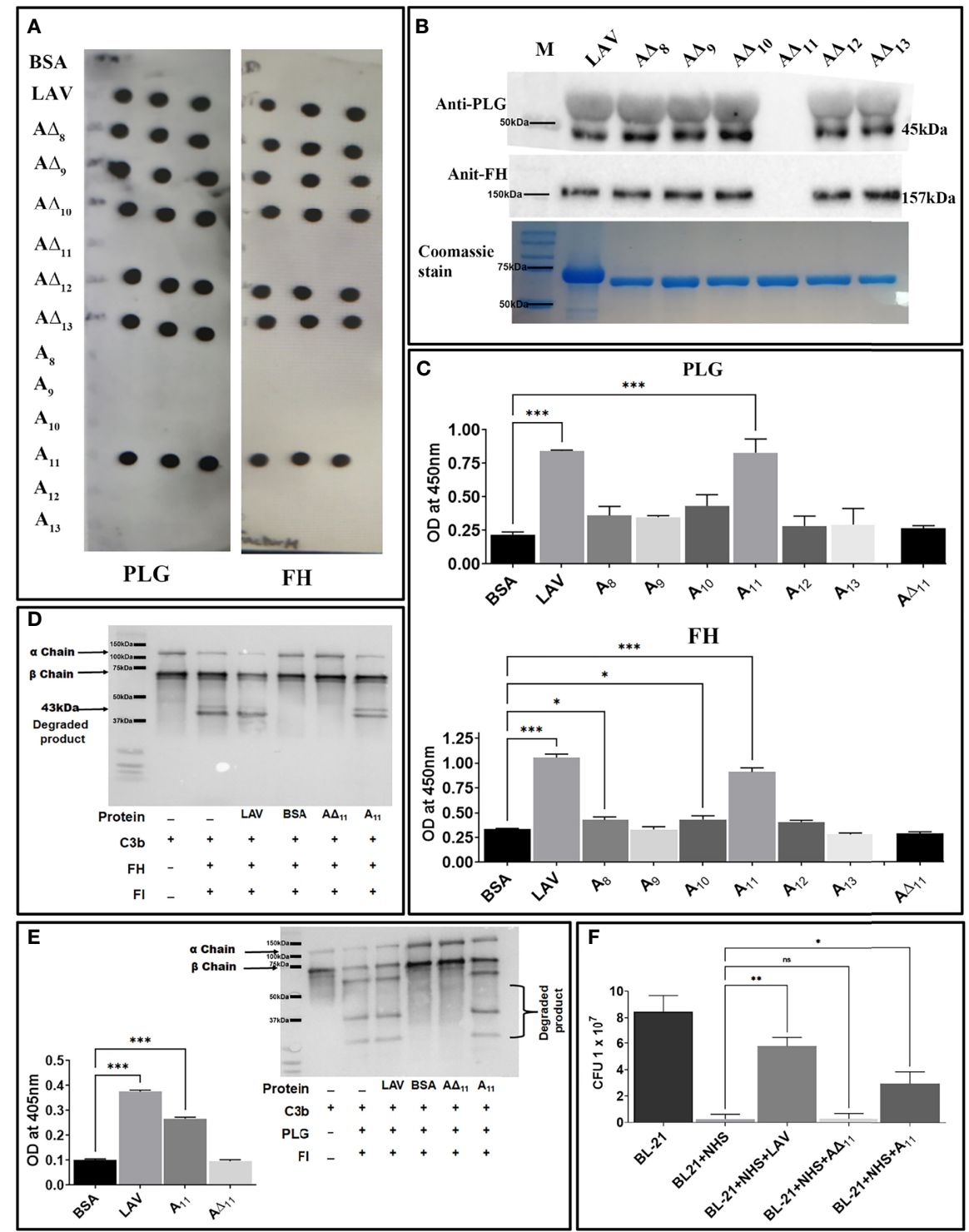

FIGURE 5 | Characterization of the domain of LAV involved in evasion from complement-mediated killing. (A) Binding of LAV domains as analyzed by Dot blot Purified proteins LAV (positive control), BSA (negative control), individual domains $\left(A_{8}-A_{13}\right)$, and corresponding deletion mutants $\left(A \triangle_{8}-A \triangle_{13}\right)$ were immobilized on nitrocellulose membranes and then incubated with $1 \%$ NHS (as a source of FH and PLG). FH and PLG were detected with specific antibodies by Western blot. (B) Binding of LAV deletion mutants as analysed by Pull down assay. Bead bound LAV deletion mutants $\left(\mathrm{A} \triangle_{8}-\mathrm{A} \triangle_{13}\right)$ were incubated with $10 \% \mathrm{HI}$ NHS and protein -protein interaction was detected by western blot using Anti FH (157 kDa) or PLG antibody (45 kDa) as described in methodology (C) Binding of LAV domains as analyzed by ELISA. Microtiter plates were coated with $1 \mu \mathrm{g}$ of proteins $L A V$, domains $\left(A_{8}-A_{13}\right)$, and corresponding deletion mutants $\left(A \triangle_{8}-\right.$ $\mathrm{A} \triangle_{13}$ ) and $10 \% \mathrm{HI}-\mathrm{NHS}$ was added to each well. The binding was detected with specific antibodies against FH and PLG as described in materials and methods. (D) Co-factor activity. LAV, $A_{11}, A \triangle_{11}(2 \mu \mathrm{g} / \mathrm{ml})$, and BSA $(2 \mu \mathrm{g} /$ well) were immobilized on microtiter plates and incubated with purified FH. After washing, $\mathrm{C} 3 \mathrm{~b}$ and factor I (FI) were added, and the plate was incubated for $4 \mathrm{~h}$ at $37^{\circ} \mathrm{C}$. The products were analysed by SDS-PAGE, and the cleavage fragments of C3b was detected by Western blot using anti-human C3 polyclonal antibodies as described in materials and methods. (E) Plasmin activity. LAV, $\mathrm{A}_{11}, \mathrm{~A} \triangle_{11}(2 \mu \mathrm{g} / \mathrm{ml})$, and BSA $(2 \mu \mathrm{g} /$ well) were immobilized on microtiter plates followed by the addition of PLG, uPA, and specific plasmin substrate. The plate was incubated for $48 \mathrm{~h}$, and absorbance was read at $405 \mathrm{~nm}$ as described in materials and methods. In another experiment, C3b was incubated with activated plasmin in the presence or absence of $A_{11}$ and cleavage products were visualized using Western blot. (F) Bactericidal assay. $1.3 \times 10^{8}$ E. coli BL-21 (DE3) cells were incubated with $10 \% \mathrm{NHS}$ with or without pre-incubation with $A_{11}$ or $A \triangle_{11}$ or $L A V$ at $20 \mu \mathrm{g} / \mathrm{ml}$ for 30 min at $37^{\circ} \mathrm{C}$. The samples were plated on LB agar plates and incubated at $37^{\circ} \mathrm{C}$ overnight. Survival was determined by counting bacterial colonies the following day. All data are representative of three independent experiments. Significant differences were calculated using the one or two way ANOVA (***, ${ }^{* \star},{ }^{*}$, ns indicates $\mathrm{P}<0.01, \mathrm{P}<0.01, \mathrm{P}<0.05$ and non-significant respectively). 


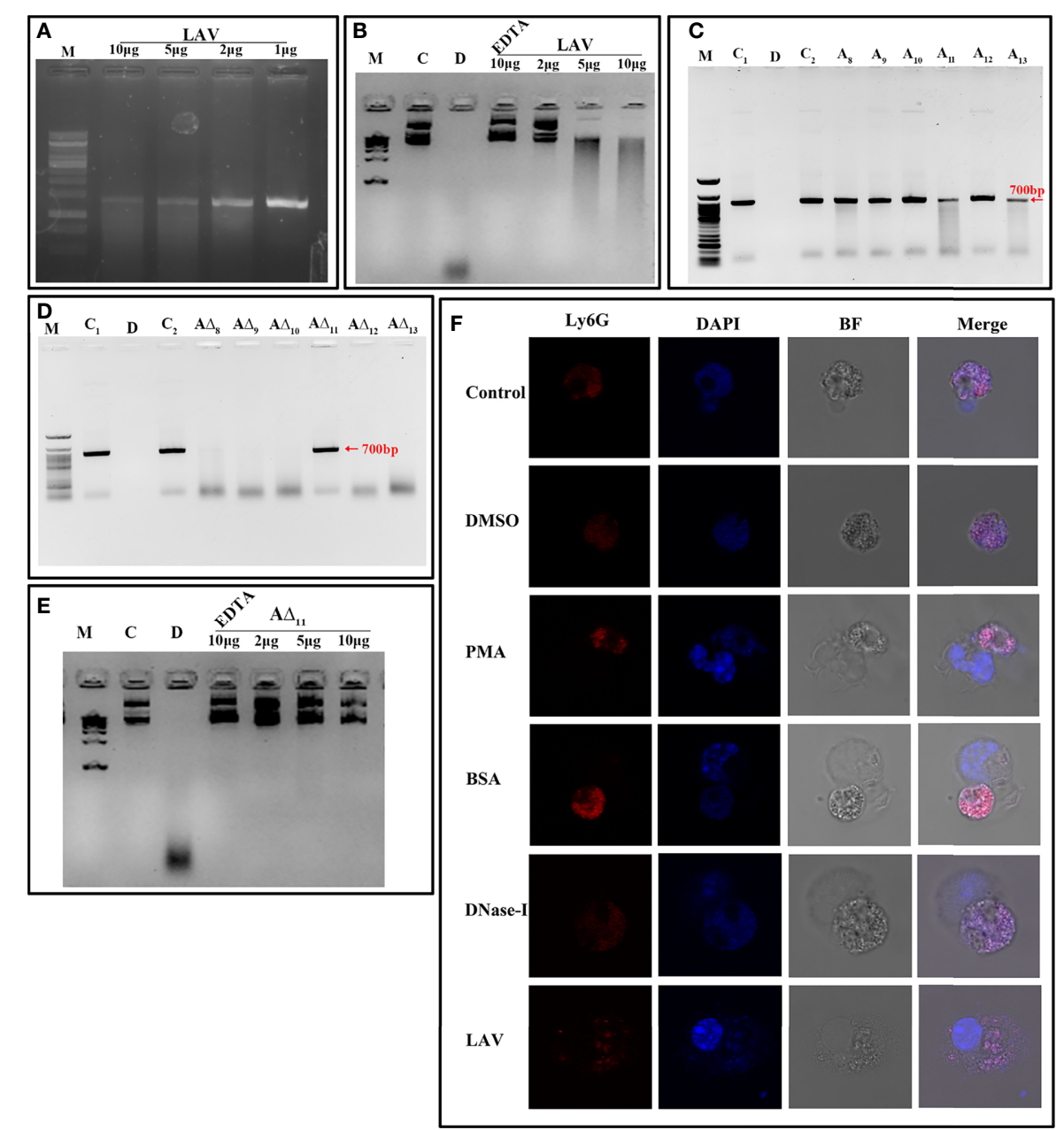

FIGURE 6 | LAV is nuclease capable of degrading Neutrophil Extracellular Trap (NET). (A) Exonuclease activity of the LAV. 700bp DNA (200ng) was incubated with different concentrations of $\operatorname{LAV}(1,2,5$ and $10 \mu \mathrm{g})$ in DPBS with $5 \mathrm{mM} \mathrm{MgCl}_{2}$ at $37^{\circ} \mathrm{C}$ for $3 \mathrm{~h}$ followed by visualized using the EtBr- Agarose gel electrophoresis. (B) Endonuclease activity of the LAV. Plasmid DNA (200ng) was incubated with different concentrations of LAV (2, 5 and $10 \mu g)$ in DPBS with $5 \mathrm{mM} \mathrm{MgCl} 2$ at $37^{\circ} \mathrm{C}$ for $3 \mathrm{~h}$ followed by visualized using the EtBr-Agarose gel electrophoresis. (C) Exonuclease activity of the LAV domains. 700bp DNA (200ng) with incubated with various LAV domains $\left(\mathrm{A}_{8}-\mathrm{A}_{13}\right)$ at $5 \mu \mathrm{g}$ in DPBS with $5 \mathrm{mM} \mathrm{MgCl} 2$ incubated at $37^{\circ} \mathrm{C}$ for $3 \mathrm{~h}$ followed by EtBr- Agarose gel electrophoresis. (D) Exonuclease activity of domain deletion mutants of LAV. DNA (200ng) with incubated with various domain deletion mutants of $L A V\left(A \triangle_{8}-A \triangle_{13}\right)$ at $5 \mu g$ in $\mathrm{DPBS}$ with $5 \mathrm{mM} \mathrm{MgCl} 2$ incubated at $37^{\circ} \mathrm{C}$ for $3 \mathrm{~h}$ followed by EtBr- Agarose gel electrophoresis (E) Endonuclease activity of the $\mathrm{A} \triangle_{11}$. Plasmid DNA (200ng) was incubated with different concentrations of $\mathrm{A} \triangle_{11}$ (2, 5 and $10 \mu \mathrm{g})$ in DPBS with $5 \mathrm{mM} \mathrm{MgCl}_{2}$ with or without EDTA at $37^{\circ} \mathrm{C}$ for $3 \mathrm{~h}$ followed by visualized using the EtBr- Agarose gel electrophoresis. C and C1 indicates DNA alone, D indicates DNA treated with DNase-I, C2 indicates DNA with reaction mixture, M is 100bp or 1 kb DNA ladder in all experiments wherever indicated (F). NETosis assay: Mouse Neutrophils were cultured on imaging dishes stimulated with DMSO or LPS (500ng) or PMA (50ng/ml) for 3h and then treated with DNase-I (positive control) or $\mathrm{BSA}$ (negative control) or LAV $(5 \mu \mathrm{g})$ for $2 \mathrm{~h}$ at $37^{\circ} \mathrm{C}$ and visualized under $63 \mathrm{X}$ of Leica microscopy. DAPI; staining of the complete DNA content (Nuclear and released), Ly6G; neutrophil marker, BF; Bright field. All data are representative of three independent experiments.

modulate their expression or undergo variations thereby enabling the bacteria to evade this innate recognition as has been reported for other pathogens. Several surface proteins of Leptospira have been identified as ligands of TLR2 or TLR4 capable of activating the innate immune response and are potential vaccine candidates $(22,24,49-51)$. Lig proteins are important virulence factors, and their expression during infection or loss of expression during in vitro culture has been correlated to virulence of the infecting serovar $(34,52)$. These proteins interact with various host molecules, including extracellular matrix (ECM), coagulation cascade, and complement regulators. LigA is the most promising vaccine candidate. It has been demonstrated that the variable region of the protein comprising domains $10-13\left(\operatorname{LigA}_{10-13}\right)$ is sufficient in inducing protection against challenge in the hamster model (3639). Thus, the diverse functions of LigA prompted us to investigate whether their role is limited to binding to host ECM and complement regulators, or they are also involved in the modulation of the host innate immune response, thereby contributing to infection and persistence in the host.

Since several investigators have established the protective role of a variable region of LigA (LAV), we chose to decipher its role 
in the modulation of the host innate immune response. We cloned, expressed and purified the recombinant LAV and tested its ability to activate mouse macrophages. Our result shows that LAV could activate macrophages, as evident from the production of pro-inflammatory cytokines (Figure 1). This effect was not due to contaminating LPS as pretreatment with Polymixin B didn't attenuate, whereas digestion with Proteinase K abrogated the cytokine production (Supplementary Figure 1B). The LAVinduced activation was TLR4 dependent as evident from its binding to the receptor, induction of IL- 8 by TLR 4 transfected HEK293 cells, and abrogation of cytokine production in TL4KO mouse macrophages. We expected that LAV might not signal through TLR2 as it is devoid of the signal sequence and hence lipidation. However, several non-acylated proteins like LcrV from Yersinia, MPB83, and PPE18 from Mycobacterium, PorB from Neisseria and FimA from $P$. gingivalis have been shown to signal through TLR2 (53-57). Although rare, several proteins from other bacterial pathogens have been reported to induce TLR4 dependent production of pro-inflammatory cytokines and expression of surface markers $(58,59)$. Further, lipidated recombinant proteins, which usually signal through TLR2 due to the lipid moiety, may signal through TLR4 if unlipidated as has been observed in the case of Omp16 and Omp19 of Brucella (60, 61). Moreover, recombinant unlipidated rBCSP31 from Brucella abortus and rLsa21 from Leptospira have been shown to signal through both TLR2 and TLR4 and induce activation of macrophages $(24,62)$. Since LAV is composed of several immunoglobulin-like repeat domains, we attempted to identify the domain involved in innate immune activation. Our results shows that $A_{11}$ is involved in TLR4 dependent activation of mouse macrophages leading to production of pro-inflammatory cytokines and expression of costimulatory molecules and maturation marker (Figures 2 and 3). Further, $A_{11}$ modulated the expression of several innate responses related to genes (cytokines, chemokines, and surface receptors) involved in the activation and maturation of macrophages (Figure 3). Our results are in accordance with previous reports, where several TLR4 ligands, including bacterial proteins, have been shown to activate macrophages and DCs via signalling through the MAP kinase pathway, leading to the induction of cytokines, expression of surface markers, and immune response-related genes $(59,63-$ 66). Since TLR, dependent activation of innate response, is essential for $\mathrm{T}$ cell expansion, differentiation, and memory formation, we tested the adaptive response induced by $\mathrm{A}_{11}$ in mice. Our result shows that the strong innate response induced by $A_{11}$ also correlated to the generation of higher level of adaptive response (Figure 4). Interestingly the response generated against $A_{11}$ was equivalent to LAV and was significantly decreased in terms of antibody titer, cell proliferation, and cytokines in the absence of this domain, indicating that $\mathrm{A}_{11}$ is the most immuno-dominant domain capable of inducing robust antibody and $\mathrm{T}$ cell response. Although $\mathrm{A}_{11}$ induced mixed Th1 and Th2 response, high levels IFN- $\gamma$ may be correlated to strong activation of innate response, particularly innate $\mathrm{B}$ cells, which require investigation (67). The strong adaptive response induced by $A_{11}$ without any adjuvant highlights its immunomodulatory potential. It suggests that TLR4 dependent signaling by $A_{11}$ might activate strong innate and subsequent adaptive response leading to clearance of Leptospira from the host. We speculate that to evade this protective response, Leptospira might limit expression or undergo antigenic variation in LigA to avoid recognition with TLR4 and subsequent activation of the innate and adaptive response. However, this needs to be tested, and experiments are ongoing. Further, the inability of $\mathrm{A} \Delta_{11}$ to activate a strong innate and subsequent adaptive response is not due to misfolding, as mutant protein retains significant numbers of alpha-helix and beta sheets as revealed by structural analysis (Supplementary Figure 2).

It is known that pathogenic Leptospira is resistant to the bactericidal activity of normal human serum (NHS) $(68,69)$. They can evade complement attack by using various strategies like recruitment of the host complement regulators, acquisition of host proteases or secretion of proteases that can cleave complement components on the bacterial surface and in its surroundings (8). Several surface proteins of Leptospira like LenA, LenB, LcpA, Lsa30, including Lig proteins (LigA and LigB) have been shown to bind to various complement regulators $(19,25-30,42,43,70-73)$. Moreover, both conserved and the variable ( $\mathrm{N}$ and $\mathrm{C}$ terminal) regions of LigA and LigB are involved in binding to $\mathrm{FH}$ and C4BP. Our results confirmed the previous report of binding of LAV with $\mathrm{FH}$ and PLG and identified and characterized the domain/s involved in binding and mediating subsequent co-factor or plasmin activity (Figure 5). Additionally, the rescue of E. coli from complementmediated killing in NHS pre-incubated with $A_{11}$ further substantiates the critical role of this domain in complement evasion (74) (Figure 5F). Thus, the protection from bacterial killing could be explained by ability of $\mathrm{A}_{11}$ to bind to both $\mathrm{FH}$ and PLG and simultaneously inhibiting lectin and alternate pathway of complement-mediated killing (Figure 5 and Supplementary Figure 4).

Apart from killing bacterial pathogens by intracellular ROS and phagocytosis, neutrophils might release neutrophils extracellular traps (NETs) that capture and kill microbes in the extracellular space in tissues (at sites of infection) or within blood vessels $(16,75)$. This mechanism on killing extracellular bacteria by trapping outside the cell is independent of phagocytosis and degranulation (16). Several bacterial pathogens, including Staphylococcus aureus, Clostridium perfringens and Streptococcus pyogenes have evolved sophisticated mechanisms to suppress, escape, and/or resist NETs through surface proteins having nuclease activity (76-78). Recently, it has been shown that Leptospira can induce the NET, and its surface protein LipL21 can modulate neutrophil function; however, nuclease capable of degrading NET has not been reported $(17,31)$. Our study discovered the nuclease (DNase) activity of LAV and demonstrated that $A_{11}$ primarily or predominantly mediates this activity as it was able to degrade DNA with the same propensity as LAV (Figure 6). Our results further demonstrate that LAV or $\mathrm{A}_{11}$ exhibits both endo and exonuclease activity. Although nuclease activity of LAV is not restricted to $A_{11}$, as 
significant activity was also mediated by $\mathrm{A}_{13}$ but our result clearly shows that it is primarily mediated by $A_{11}$. The ability of LAV to degrade PMA induced NET in mouse neutrophils and highlights the possible role of LigA in escaping the bacteria from NETosis. To our knowledge, this is the first report of identification of nuclease activity of a surface protein in Leptospira and also demonstrating its diverse role in modulating the host innate response.

In conclusion, our results demonstrate that LigA is a multifunctional protein involved in attachment to host cells to initiate infection, a TLR4 agonist which can activate a strong innate response (possibly evading this TLR4 activation by antigen variation or downregulating its expression upon infection in the host), binds to complement regulators to evade complement-mediated killing and exhibit nuclease activity when Leptospira gets entrapped in NET (Figure 7). These features might contribute to its successful colonization in a particular host. Interestingly, these functions are mediated primarily by a single domain $\left(\mathrm{A}_{11}\right)$ which lies in LAV. This promising vaccine candidate conferred protective immunity against lethal infection in the hamster model of the disease. Thus, the protective efficacy of LAV based vaccine may be correlated with its ability to induce the robust antigen-specific humoral and $\mathrm{T}$ cell response that might lead to the generation of antibodies conceivably blocking binding to host extracellular matrix, acquiring complement regulators and inhibiting DNase activity all of these may aid in the clearance of bacteria from the host (Figure 7). Our results provide important insight into the role of LAV in host-pathogen interaction and also established it as an immuno-modulator or adjuvant, which makes it an ideal candidate for developing vaccines for this dreadful zoonosis (79).

\section{MATERIAL AND METHODS}

\section{Animals, Cell Lines and Reagents}

Male C57BL/6J mice (6-8 weeks) were obtained from the Animal Resource and Experimental Facility of NIAB, Hyderabad. The original breeding colonies were obtained from Jackson Labs, USA. The animals were maintained in a pathogen-free condition. All the procedures for animal experiments were approved by the Institutional Animal Ethics Committee (IAEC) and performed in accordance with the Committee for the Purpose of Control and Supervision of Experiments on Animals (CPCSEA) guidelines. RAW264.7 and HEK293 cell lines were originally purchased from the ATCC (Manassas, VA). Mouse macrophage WT (NR-9456), TLR2KO (TLR2-/-, NR-9457), TLR4KO (TLR4-/-, NR-9458), DKO (TLR2-/-/4-/-, NR-19975), TRIFKO (TRIF-/-, NR-9566), MyD88KO (MyD88-/-, NR-15633) and TMDKO (TRIF-/-MyD88-/-, NR-15632), cell lines were obtained from BEI Resources, USA. Cells were cultured in DMEM (Sigma, USA) supplemented with 10\% FBS (Invitrogen, Carlsbad, CA, USA), penicillin $(100 \mathrm{U} / \mathrm{ml})$, and streptomycin $(100 \mu \mathrm{g} / \mathrm{ml})$ and maintained at $37^{\circ} \mathrm{C}$ in a humidified incubator (5\% CO2). Pharmalogical inhibitors of NF-kB (SN50), p38 (SB203580), ERK (U0126) and JNK

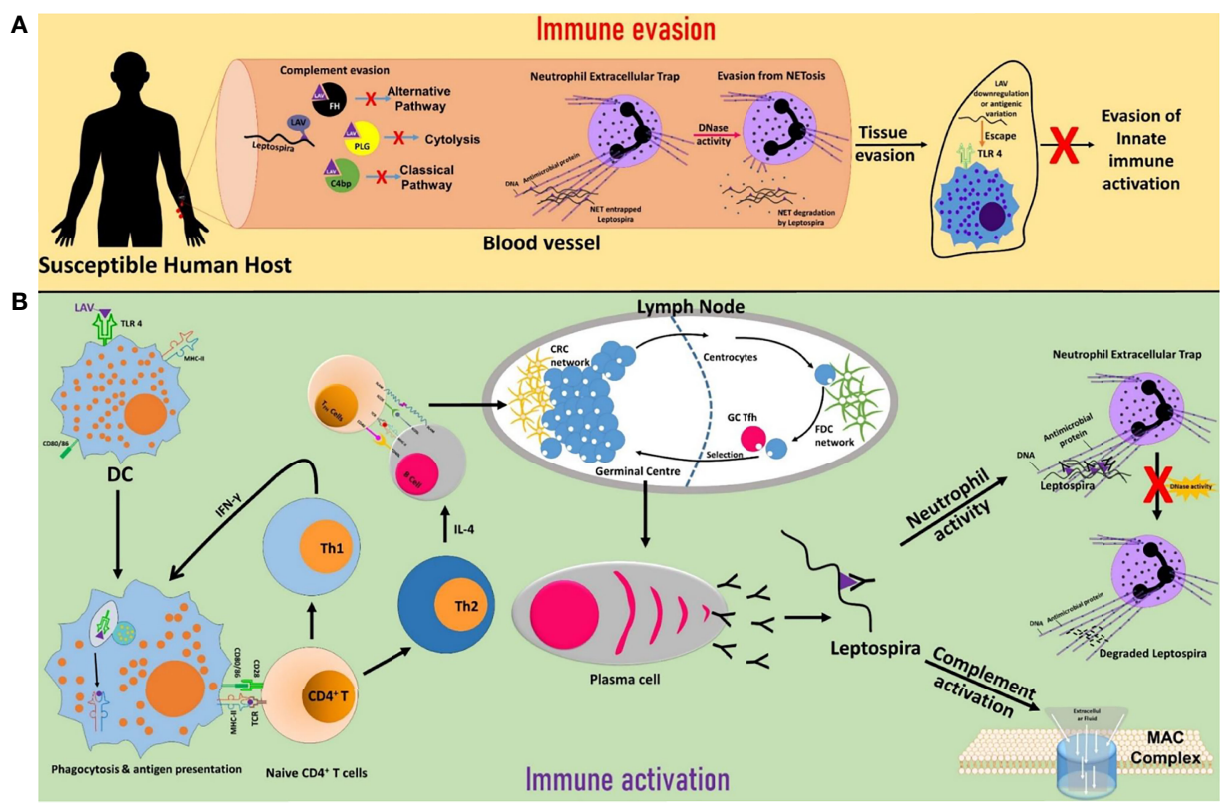

FIGURE 7 | Schematic presentation of the role of LigA in the modulation of host immune response. (A) Immune evasion. LigA expressed during infection might acquire complement regulators (FH, C4BP, PLG) to inhibit both the classical and alternate pathways of complement-mediated killing. Leptospira might utilize the nuclease activity of LigA to escape from NET. Upon interaction with host innate immune cells (DCs, macrophages), LigA might undergo antigenic variation or downregulate its expression to evade recognition through TLR4 and subsequent activation of the innate response. (B) Immune activation. LigA can activate strong innate and adaptive immune responses leading to the production of antibodies that may block binding to complement regulators, inhibit nuclease activity and enhance phagocytosis, all of which may contribute to the killing of bacteria and clearance from the host. 
(SP600125) were purchased from Invivogen. Mouse IL-6 and TNF- $\alpha$ Sandwich ELISA kits were from R\&D Biosystems. APC conjugated hamster antimouse-CD80, PE-conjugated rat antimouse-CD86, BV421 conjugated rat antimouse-CD40 and Per Cp Cy5.5 conjugated rat antimouse-MHC-II antibodies were procured from BD biosciences, US. Normal Human Serum (S1$100 \mathrm{ml})$, Goat anti FH (SAB2500260), Mouse anti PLG (SAB1406263-50UG), Plasmin substrate, uPA (SRP6273) complement C3b (204860-250G) Complement factor I (C5938$1 \mathrm{MG})$, Complement factor H (C5813-1MG), plasminogen (SRP6518-1MG) were procured from Sigma-Aldrich Chemical co., USA. Polyclonal anti C3 was purchased from Complement Technology, USA.

\section{Cloning, Expression, and Purification of Recombinant Proteins}

The Lig A variable (LAV) gene sequence was amplified by PCR from L. interrogans serovar Pomona strain genomic DNA using specific primers and then cloned in His-Sumo tagged pET28a expression vector. Domains of LAV 8 to $13\left(\mathrm{~A}_{8}-\mathrm{A}_{13}\right)$ and corresponding deletion mutants $\mathrm{A} \Delta_{8}-\mathrm{A} \Delta_{13}$ were similarly cloned in the pET28a vector. Various domain deletion mutants of LAV $\left(\mathrm{A} \Delta_{8}-\mathrm{A} \Delta_{13}\right)$ were generated by PCR-based site-directed mutagenesis. All the clones were verified by sequencing. The plasmid was transformed into $B L-21$ (DE3) Rosetta. The resulting transformants were grown at $37^{\circ} \mathrm{C}$ overnight on $\mathrm{LB}$ broth containing $50 \mu \mathrm{g} / \mathrm{ml}$ kanamycin, and the expression of the protein was induced with $1 \mathrm{mM}$ isopropyl $\beta$-D-1-thiogalactoside (IPTG). The cells were harvested by centrifugation at 10,000 $\mathrm{rpm}$, and the cell pellet was resuspended in $100 \mathrm{mM}$ Tris $\mathrm{HCl}$, $150 \mathrm{mM} \mathrm{NaCl} \mathrm{pH} 8.0$, followed by sonication at constant pulses. The lysate was centrifuged to remove cell debris, and the supernatant was subjected to affinity chromatography using Ni-NTA beads column (Takara). Eluted protein was dialyzed against $1 \times \mathrm{PBS}$ with four changes for two days at $4^{\circ} \mathrm{C}$. The protein was then passed through Detox- Gel (Pierce, USA) to remove any contaminating LPS from E. coli, and a residual trace amount of LPS was monitored by Limulus amoebocyte lysate (LAL, Endotoxin Detection Kit, Pierce, Thermo, USA) assay following the manufacturer's instructions. The purified protein was checked for size and purity by SDS-PAGE, and concentration was estimated using the Bradford reagent (Sigma, USA).

\section{Cell Stimulation Assays by Cytokine ELISAs}

Cytokine ELISA kits (R\&D systems) were used to measure cytokine levels, following the manufacturer's instructions. RAW264.7 cells were stimulated with LAV or $\left(A_{8}-A_{13}\right)$ or corresponding deletion mutants $\left(\Delta \mathrm{A}_{8}-\mathrm{A} \Delta_{13}\right)(2 \mu \mathrm{g} / \mathrm{ml})$, PAM3CSK4 (20ng/ml), and E. coli LPS 0111-B4 (500ng/ml) for $24 \mathrm{~h}$ at $37^{\circ} \mathrm{C}$ in the presence of $5 \% \mathrm{CO}_{2}$ and cytokines (IL-6, TNF- $\alpha$ ) were measured in the culture supernatant according to the manufacturer instructions. The proteins were pre-treated with Polymyxin B (20ng/mg protein) at $37^{\circ} \mathrm{C}$ for $1 \mathrm{~h}$ and proteinase $\mathrm{K}\left(5 \mu \mathrm{g} / \mathrm{mg}\right.$ protein) at $65^{\circ} \mathrm{C}$ for $1 \mathrm{~h}$ followed by inactivation at $95^{\circ} \mathrm{C}$ for $5 \mathrm{~min}$ before each assay to rule out endotoxin activity. In a separate experiment wild type, TLR2KO, TLR4KO, DKO, MyD88KO, TRIFKO, TMDKO macrophage cell lines were stimulated with PAM3CSK4, LPS, LAV or $\mathrm{A}_{11}$ or $\mathrm{A} \Delta_{11}$ for $24 \mathrm{~h}$ at $37^{\circ} \mathrm{C} / 5 \% \mathrm{CO}_{2}$ and cytokines (IL-6, TNF- $\alpha$ ) in the culture supernatant were measured by ELISA kit as per manufacturer's instructions. HEK-293T cells were cultured in a complete DMEM medium for $24 \mathrm{~h}$ at $37^{\circ} \mathrm{C}$ in the presence of $5 \%$ $\mathrm{CO}_{2}$ and transfected with mouse TLR2 (mTLR2), mouse TLR4 (mTLR4), and NF-kB reporter plasmids using X-fect Transfection reagent (Takara, Japan) following manufacturer's protocol. Cells were stimulated with LAV $(2 \mu \mathrm{g} / \mathrm{ml})$ for $24 \mathrm{~h}$, and then IL-8 levels were measured in the cell culture supernatant. To assess the signaling pathway involved, additional experiments were done in which RAW264.7 cells were pre-treated for 30min at $37^{\circ} \mathrm{C} / 5 \% \mathrm{CO}_{2}$ with pharmacological inhibitors of $\mathrm{NF}-\mathrm{kB}$ $(\mathrm{SN} 50 ; 20 \mu \mathrm{M})$ or JNK $(\mathrm{SP} 600125 ; 40 \mu \mathrm{M})$ or p-38MAPK $(\mathrm{SB} 203580 ; 30 \mu \mathrm{M})$ or ERK $(\mathrm{U} 0126 ; 20 \mu \mathrm{M})$ followed by treatment with $\mathrm{A}_{11}(2 \mu \mathrm{g} / \mathrm{ml})$ for $24 \mathrm{~h}$ at $37^{\circ} \mathrm{C}$ in the presence of $5 \% \mathrm{CO}_{2}$. Cytokine levels were measured by ELISA kit.

\section{Flow Cytometric Analysis}

RAW264.7 cells were incubated in 6-well plates $\left(0.3 \times 10^{6}\right.$ cells/well $)$ with PAM3CSK4 $(20 \mathrm{ng} / \mathrm{ml})$, LPS $(500 \mathrm{ng} / \mathrm{ml})$, LAV or $\mathrm{A}_{11}$ or $\mathrm{A} \Delta_{11}$ $(2 \mu \mathrm{g} / \mathrm{ml})$ for $24 \mathrm{~h}$ at $37^{\circ} \mathrm{C}$ in the presence of $5 \% \mathrm{CO}_{2}$. Cells were harvested and washed with pre-chilled PBS and then incubated on ice for $1 \mathrm{~h}$ in the dark with respective fluorochrome conjugated antibodies against CD80, CD86, MHC-II, and CD40. Cells were washed and then fixed with 1\% paraformaldehyde, and 50,000 total events/sample were acquired using a BD Fortessa. The data were analyzed using FlowJo software.

\section{Preparation of Antisera}

Male C57BL/6J mice (6-8 weeks) were immunized subcutaneously on days 0 with $20 \mu \mathrm{g}$ of $\mathrm{LAV}, \mathrm{A}_{11}, \mathrm{~A} \Delta_{11}$ in complete Freund's adjuvant (CFA) and then boosted on day 21 with $10 \mu \mathrm{g}$ of proteins in Incomplete Freund's adjuvant (IFA). Sera were collected one week after booster (day 28) and titer were determined using ELISA. The mouse serum having anti-LAV, anti- $\mathrm{A}_{11}$ or anti-A $\Delta_{11}$ antibodies were used in confocal microscopy.

\section{TLR Binding Assay}

WT, TLR2KO, TLR4KO and DKO cell lines were grown overnight on glass-bottom cell imaging dishes (Eppendorf) and then incubated for $30 \mathrm{~min}$ at $37^{\circ} \mathrm{C}$ in the presence of $5 \% \mathrm{CO}_{2}$ with LAV or $\mathrm{A}_{11}$ or $\mathrm{A}_{11}(2 \mu \mathrm{g} / \mathrm{ml})$ in DMEM without FBS. The cells were washed with PBS and fixed for 15 min using $4 \%$ paraformaldehyde followed by blocking with 5\%FBS in PBS for $30 \mathrm{~min}$ at RT. The cells were then incubated with anti-LAV or $\mathrm{A}_{11}$ or $\mathrm{A} \Delta_{11}$ (mouse serum, 1:100 dilution) for $1 \mathrm{~h}$, washed three times with PBS, and then stained with Alexa Flour 647 conjugated rabbit anti-mouse IgG (Biolegend, USA). Cells were extensively washed and mounted with VECTA SHIELD (containing DAPI) mounting medium and observed using a $63 \mathrm{x}$ oil objective on a confocal microscope (Leica SP8, Wetzlar, Germany). 


\section{RT-PCR}

WT, TLR2KO, TLR4KO and DKO mouse macrophage cell lines were treated with $\mathrm{A}_{11}(2 \mu \mathrm{g} / \mathrm{ml})$, LPS $(500 \mathrm{ng} / \mathrm{ml})$ or PAM3CSK4 (20ng/ml). After 4, 24 and $48 \mathrm{~h}$ of treatment cells were recovered in $500 \mu \mathrm{l}$ of TRIzol (Invitrogen, Carlsbad, CA), and equal volumes of chloroform were added; samples were centrifuged at $12000 \mathrm{rpm}$ for $15 \mathrm{~min}$ at $4^{\circ} \mathrm{C}$. The aqueous phase was then passed through RNA easy mini columns (MN) and RNA was purified following the manufacturer's protocol. RNA quality was checked by running on a Formaldehyde gel for 18s and 28s RNA bands and analyzed on Bioanalyser. The RNA quantity was assessed by UV spectroscopy and purity by 260/280 ratio. First-strand cDNA was synthesized using the superscript IIIRT system (Invitrogen) following the manufacturer's instructions. RT-PCR was performed in 96 well microtiter plates in a $10 \mu \mathrm{l}$ reaction volume containing 50ng cDNA, $10 \mu \mathrm{M}$ each primer (Supplementary Table. 1) and SYBR green (BioRad). Samples were run in triplicate, and data was analyzed with Sequence Detection System (Bio-Rad CFX-96). The experimental data were presented as fold changes of gene expression of stimulated cells at various time points relative to control. mRNA levels of the analyzed genes were normalized to the amount of GAPDH present in each sample.

\section{Circular Dichroism}

The proteins (LAV and $\mathrm{A} \Delta_{11}$ ) were dialysed against sodium phosphate buffer and the CD spectroscopy of the far-UV spectrum was obtained in a Jasco J-810 spectropolarimeter (Japan Spectroscopic). The resulting spectra are presented as the averages of three scans recorded from 190 to $260 \mathrm{~nm}$. The residual molar ellipticity is expressed in degree $\mathrm{cm} 2 \mathrm{dmol}-1$. Spectral data were analyzed with the software BESTSEL (https://bestsel.elte.hu/) for estimation of the secondary structure content.

\section{Adaptive Immune Response}

Male C57BL/6J mice (6-8 weeks) were immunized subcutaneously on days 0 with $20 \mu \mathrm{g}$ and on day 21 with $10 \mu \mathrm{g}$ of LAV or $A_{11}$ with or without Alum adjuvant. Animals vaccinated with PBS were used as control. Mice bled at various time points a (day 0,21 and 28), and the serum was analyzed for antigen-specific antibodies. Animals were euthanized on day 28 and blood, and spleens were collected for evaluation of antigenspecific immune responses. To determine antibody response, serum samples from individual mice were collected on the day before immunization and then on day 21 and 28. Total IgG, IgG1, IgG2c, and IgA concentrations were evaluated using ELISA using the standard procedure. For cell proliferation assay, splenocytes prepared from different mice groups were stimulated with varying concentrations $(1,2$ and $10 \mu \mathrm{g} / \mathrm{ml})$ of LAV or $A_{11}$ or $A \Delta_{11}$. Cells were counted under an inverted microscope at $24 \mathrm{~h}, 48 \mathrm{~h}$ and $72 \mathrm{~h}$ post-stimulation. To determine Th1 and Th2 cytokines, culture supernatant was collected at $72 \mathrm{~h}$ post antigen stimulation and were used to estimate the IL-4, IL10 and IFN- $\gamma$ using cytokine ELISA kits (R\&D systems) following the manufacturer's instructions.

\section{Dot Blot Binding Assay}

Dot blot binding assays were performed to confirm the binding of various LAV domains $\left(\mathrm{A}_{8}-\mathrm{A}_{13}\right)$ and their single domain deletion mutants $\left(\mathrm{A} \Delta_{8}-\mathrm{A} \Delta_{13}\right)$ with $\mathrm{FH}$ and serine protease PLG. $1 \mu \mathrm{g}$ of each protein (wild type, single domain, and domain deletion mutant) was immobilized onto NC membranes $(0.2 \mu$ pore size; Bio-Rad). The membranes were kept for drying for 5-10 min at RT. The membranes were then blocked with 5\% BSA in Tris-buffered Saline-Tween 20 (TBS-T) for $2 \mathrm{~h}$ at RT, washed three times with TBS-T, and incubated with $1 \%$ normal human serum (NHS) diluted in PBS with gentle shaking for $3 \mathrm{~h}$ at RT. After extensive washing with TBS-T, the membranes were incubated with the corresponding primary antibody (Goat anti-FH, Mouse anti-PLG 1: 10,000 dilution) in TBS-T for $2 \mathrm{~h}$ at RT. The membranes were then washed with TBS-T and incubated with a respective peroxidase-conjugated secondary antibody $(1: 6,000)$ for $2 \mathrm{~h}$ at room temperature. Reactive spots were developed using a chemiluminescence system with an exposure time of $10 \mathrm{sec}$.

\section{Pull Down Assay}

Each domain deletion mutants of $\operatorname{LAV}\left(\mathrm{A} \Delta_{8}-\mathrm{A} \Delta_{13}\right)$ along with $10 \%$ heat-inactivated NHS, were incubated with $15 \mu \mathrm{L}$ of NiNTA agarose beads (Takara) overnight at $4^{\circ} \mathrm{C}$. Agarose beads were washed five times with PBS containing $40 \mathrm{mM}$ imidazole and then interacting proteins were eluted with PBS containing $250 \mathrm{mM}$ imidazole. Each elutes boiled in reducing Laemmli buffer and subjected to SDS-PAGE. The proteins were transferred to nitrocellulose membrane followed by western blot against Anti- FH, and Anti-PLG, respectively.

\section{ELISA Binding Assay}

Protein binding to soluble complement regulators $\mathrm{FH}, \mathrm{C} 4 \mathrm{BP}$ and PLG were analyzed by ELISA as described previously $(26,29)$. Briefly, micro titre plates were coated overnight at $4^{\circ} \mathrm{C}$ with $1 \mu \mathrm{g}$ of domains $\left(\mathrm{A}_{8}-\mathrm{A}_{13}\right)$ and their single domain deletion mutants $\left(\mathrm{A} \Delta_{8}-\mathrm{A} \Delta_{13}\right)$. BSA and LAV were used as negative and positive controls respectively. The wells were washed three times with PBS containing $0.05 \%$ Tween 20 (PBS-T), blocked with $300 \mu \mathrm{l}$ $\mathrm{PBS} / 3 \% \mathrm{BSA}$ for $2 \mathrm{~h}$ at $37^{\circ} \mathrm{C}$, and incubated with $100 \mu \mathrm{l} 10 \% \mathrm{NHS}$ for $90 \mathrm{~min}$ at $37^{\circ} \mathrm{C}$. After washing with PBS-T, goat anti-FH (1:1000), rabbit anti-C4BP (1:1000) or mouse anti-PLG (1:5000) was added and the plate was incubated for $1 \mathrm{~h}$ at $37^{\circ} \mathrm{C}$. After washing, HRP-conjugated anti-goat or anti-mouse or anti-rabbit IgG was added and incubated for $1 \mathrm{~h}$ at $37^{\circ} \mathrm{C}$. The wells were washed and TMB substrate was added $(100 \mu \mathrm{l} /$ well $)$. The reaction was stopped by the addition of $50 \mu \mathrm{l} 2 \mathrm{~N} \mathrm{H}_{2} \mathrm{SO}_{4}$ and absorbance was measured at $450 \mathrm{~nm}$ in a microplate reader.

\section{Cofactor Activity Assay}

Cofactor activity was determined as described previously (26). Briefly, $2 \mu \mathrm{g}$ of $\mathrm{A}_{11}, \mathrm{~A} \Delta_{11}$ and LAV (positive control) or BSA (negative control) were coated on microplates overnight at $4^{\circ} \mathrm{C}$. The wells were washed and blocked with PBS/2\% BSA for $2 \mathrm{~h}$ at $37^{\circ} \mathrm{C}$, followed by the addition of $2 \mu \mathrm{g}$ pure $\mathrm{FH}$ and further incubation for $90 \mathrm{~min}$ at $37^{\circ} \mathrm{C}$. Unbounded $\mathrm{FH}$ was removed by 
washing and then 250ng FI and 500ng C3b were added to the microtiter plate wells and incubated for $3-5 \mathrm{~h}$ at $37^{\circ} \mathrm{C}$. The supernatants were loaded onto a 10\% SDS-PAGE gel and transferred onto a $0.22 \mu$ PVDF membrane. For the immunoblotting, membranes were blocked with 5\% BSA and then incubated with goat anti-human C3 (1:5000) for 2h at RT. After the usual steps of washing, the membranes were incubated with a peroxidase-conjugated secondary antibody. The images were visualized under the Clarity Max Western ECL substrate (BIO-RAD) using Syngene G: BOX Chemi XX6/XX9.

\section{Plasmin Activity Assay}

Plasmin activity was determined as described previously (26). Briefly, Microtiter plate wells were coated overnight at $4^{\circ} \mathrm{C}$ with $2 \mu \mathrm{g}$ LAV (positive control), BSA (negative control), $\mathrm{A}_{11}, \mathrm{~A} \Delta_{11}$. The plate was washed with PBS-T and blocked for $2 \mathrm{~h}$ at $37^{\circ} \mathrm{C}$ with $10 \%$ skim milk. After discarding the blocking solution, human PLG $(2 \mu \mathrm{g} /$ well $)$ was added, followed by incubation for 90

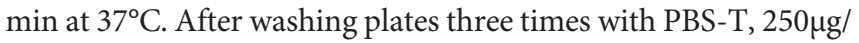
$\mathrm{ml}$ uPA was added with the plasmin-specific substrate, $D$-ValLeu-Lys 4 - $p$-nitroanilide dihydrochloride $(100 \mu \mathrm{l} /$ well $)$ at a final concentration of $0.4 \mathrm{mM}$ in PBS. Plates were incubated for $24 \mathrm{~h}$ at $37^{\circ} \mathrm{C}$, and absorbances were measured at $405 \mathrm{~nm}$ using a microplate reader.

\section{Bactericidal Assay}

Bactericidal activity was determined as described elsewhere (26). $1.3 \times \times 10^{8}$ E. coli BL-21 (DE3) cells were washed once with PBS and incubated with $10 \%$ NHS with or without pre-incubation with recombinant proteins $\left(\mathrm{A}_{11}, \mathrm{~A} \Delta_{11}, \mathrm{LAV}\right.$ at $\left.20 \mu \mathrm{g} / \mathrm{ml}\right)$ in a final reaction volume of $100 \mu \mathrm{l}$ for $30 \mathrm{~min}$ at $37^{\circ} \mathrm{C}$. The samples were placed on ice to stop further bacteriolysis and then plated on $\mathrm{LB}$ agar plates. The plates were incubated at $37^{\circ} \mathrm{C}$ overnight. Survival was determined by counting bacterial colonies the following day.

\section{Nuclease Activity}

To examine the DNase activity of LAV, 200ng of 700bp DNA was incubated with different concentration ( 1 or 2 or 5 or $10 \mu \mathrm{g}$ ) of LAV or $2 \mu \mathrm{g}$ domains $\left(\mathrm{A}_{8}-\mathrm{A}_{13}\right)$ and $2 \mu \mathrm{g}$ domain deletion mutants $\left(\mathrm{A} \Delta_{8}-\mathrm{A} \Delta_{13}\right)$ or DNase I (20IU, positive control) in DPBS with $5 \mathrm{mM} \mathrm{MgCl}_{2}$ in a PCR tube at $37^{\circ} \mathrm{C}$ for $2 \mathrm{~h}$. The reaction mixture was subjected to $\mathrm{EtBr}$ Agarose gel electrophoresis (1\%) and then observed under the Gel doc. In a separate experiment, a plasmid was used as a substrate to check endonuclease activity of various concentrations (2ug, 5ug, and $10 \mathrm{ug}$ ) of LAV or $\mathrm{A} \Delta_{11}$. EDTA is a nuclease activity inhibitor, was used as control.

\section{Isolation of Neutrophils From Murine Bone Marrow}

Neutrophils were isolated from the bone marrow of C57BL/6J mice using the standard procedure (80). Briefly, bone marrow was flushed from femurs using a $26 \mathrm{G}$ needle, passed through a $30 \mu \mathrm{m}$ cell strainer, and then cells were washed in complete RPMI-1640 twice at $1,400 \mathrm{rpm}$ for $10 \mathrm{~min}$ at $4^{\circ} \mathrm{C}$. After lysis of
RBCs using ACK lysis buffer, cells were washed with RPMI-1640 supplemented with $10 \%$ FBS, counted, and resuspended in $1 \mathrm{ml}$ of ice-cold sterile PBS. Next, cells were overlaid on $3 \mathrm{ml}$ of Histopaque $1077 / 1119 \mathrm{mix}$ in a $15 \mathrm{ml}$ conical tube and then centrifuged for $30 \mathrm{~min}$ at $2,000 \mathrm{rpm}$ at $25^{\circ} \mathrm{C}$ without braking. Neutrophils at the interface were collected and washed twice with a complete RPMI-1640 medium, counted and suspended in the medium for the specific assay. The viability was determined by Trypan blue exclusion assay.

\section{NET Assay}

$2 \times 10^{5}$ freshly isolated neutrophils in $300 \mu \mathrm{l}$ medium were added to the imaging dish and kept at $37^{\circ} \mathrm{C}$ in the presence of $5 \% \mathrm{CO}_{2}$ overnight. Cells were treated with $3 \mu \mathrm{l}$ of DMSO or PMA (50ng/ $\mathrm{ml}$ ) and further incubated for $3 \mathrm{~h}$ at $37^{\circ} \mathrm{C} / 5 \% \mathrm{CO}_{2}$. Cells were washed thrice with DPBS and then incubated with LAV $(2 \mu \mathrm{g} /$ $\mathrm{ml})$ or DNase-I (20IU) or BSA $(5 \mu \mathrm{g} / \mathrm{ml})$ in $5 \mathrm{mM} \mathrm{MgCl}_{2}$ containing PBS for $2 \mathrm{~h}$ at $37^{\circ} \mathrm{C} / 5 \% \mathrm{CO}_{2}$. Cells were washed with DPBS, fixed with $4 \%$ PFA (15min at RT), and then stained with Rat anti-mouse Ly6G (Alexa flour 647) for 30min. Cells were washed thoroughly with DPBS, mounted with VECTA SHIELD (with DAPI) mounting medium and observed using a $63 \mathrm{x}$ oil objective on a confocal microscope (Leica SP8, Wetzlar, Germany).

\section{Statistical Analysis}

For all the experiments, wherever required one way or two-way ANOVA were executed to analyze the results. Data were pooled from each trial for analysis. The results are presented as mean \pm SEM of four trials for a cell type in each group. Statistical analysis was conducted using an analysis of variance (ANOVA) either One way or Two way. Significant differences between the means were determined by analyzing the data for multiple comparisons using the Dunnett and Sidak statistical hypothesis test for Two way and One way ANOVA respectively. The level of significance was set at $\mathrm{P}<0.05$.

\section{DATA AVAILABILITY STATEMENT}

The original contributions presented in the study are included in the article/Supplementary Material. Further inquiries can be directed to the corresponding author.

\section{ETHICS STATEMENT}

The animal study was reviewed and approved by Institutional Animal Ethics Committee, NIAB.

\section{AUTHOR CONTRIBUTIONS}

SMF conceived the idea and designed the experiments. AK, VV, $\mathrm{KS}, \mathrm{MA}, \mathrm{PV}$, and MAT performed the experiments. AK, VV, KS, 
and SMF analyzed the data. VV made all the figures of the manuscript and did the statistical analysis. Y-FC contributed reagents and input in experiment design and data analysis. SMF, $\mathrm{AK}$, and VV wrote the initial draft, and SMF edited the manuscript. All authors approved the final version of the manuscript.

\section{FUNDING}

This work was supported partly from the DBT project- BT/ PR21430/ADV/90/246/2016 (SP025) on developing Leptospira vaccines and partly from DBT-NIAB flagship project No- BT/ AAQ/01/NIAB-Flagship/2019 (SP051) on host-pathogen interaction, which are funded to SMF from the Department of Biotechnology, Ministry of Science and Technology, Government of India. Financial support from the NIAB core fund is duly acknowledged.

\section{REFERENCES}

1. Costa F, Hagan JE, Calcagno J, Kane M, Torgerson P, Martinez-Silveira MS, et al. Global Morbidity and Mortality of Leptospirosis: A Systematic Review. PloS Negl Trop Dis (2015) 9:e0003898. doi: 10.1371/journal.pntd.0003898

2. Goarant C. Leptospirosis: Risk Factors and Management Challenges in Developing Countries. Res Rep Trop Med (2016) 7:49-62. doi: 10.2147/ RRTM.S102543

3. Grassmann AA, Souza JD, Mcbride AJ. A Universal Vaccine Against Leptospirosis: Are We Going in the Right Direction? Front Immunol (2017) 8:256. doi: 10.3389/fimmu.2017.00256

4. Medzhitov R, Janeway CJr. Innate Immune Recognition: Mechanisms and Pathways. Immunol Rev (2000) 173:89-97. doi: 10.1034/j.1600065X.2000.917309.x

5. Medzhitov R, Janeway CJr. The Toll Receptor Family and Microbial Recognition. Trends Microbiol (2000) 8:452-6. doi: 10.1016/S0966-842X (00)01845-X

6. Pasare C, Medzhitov R. Toll-Like Receptors: Linking Innate and Adaptive Immunity. Adv Exp Med Biol (2005) 560:11-8. doi: 10.1007/0-387-24180-9_2

7. Wille-Reece U, Flynn BJ, Lore K, Koup RA, Miles AP, Saul A, et al. Toll-Like Receptor Agonists Influence the Magnitude and Quality of Memory T Cell Responses After Prime-Boost Immunization in Nonhuman Primates. J Exp Med (2006) 203:1249-58. doi: 10.1084/jem.20052433

8. Zipfel PF, Wurzner R, Skerka C. Complement Evasion of Pathogens: Common Strategies Are Shared by Diverse Organisms. Mol Immunol (2007) 44:3850-7. doi: 10.1016/j.molimm.2007.06.149

9. Schmidt CQ, Lambris JD, Ricklin D. Protection of Host Cells by Complement Regulators. Immunol Rev (2016) 274:152-71. doi: 10.1111/imr.12475

10. Barthel D, Schindler S, Zipfel PF. Plasminogen Is a Complement Inhibitor. J Biol Chem (2012) 287:18831-42. doi: 10.1074/jbc.M111.323287

11. Urban CF, Lourido S, Zychlinsky A. How do Microbes Evade Neutrophil Killing? Cell Microbiol (2006) 8:1687-96. doi: 10.1111/j.14625822.2006.00792.x

12. Christodoulides A, Boyadjian A, Kelesidis T. Spirochetal Lipoproteins and Immune Evasion. Front Immunol (2017) 8:364. doi: 10.3389/fimmu.2017.00364

13. Cox DL, Chang P, Mcdowall AW, Radolf JD. The Outer Membrane, Not a Coat of Host Proteins, Limits Antigenicity of Virulent Treponema Pallidum. Infect Immun (1992) 60:1076-83. doi: 10.1128/iai.60.3.1076-1083.1992

14. Zhang JR, Norris SJ. Genetic Variation of the Borrelia Burgdorferi Gene vlsE Involves Cassette-Specific, Segmental Gene Conversion. Infect Immun (1998) 66:3698-704. doi: 10.1128/IAI.66.8.3698-3704.1998

15. Reddick LE, Alto NM. Bacteria Fighting Back: How Pathogens Target and Subvert the Host Innate Immune System. Mol Cell (2014) 54:321-8. doi: 10.1016/j.molcel.2014.03.010

\section{ACKNOWLEDGMENTS}

The authors would like to thank the Director, NIAB, Dr. Subeer S. Majumdar, for providing the necessary infrastructural facility and support for the execution of the above study. Thanks to Mr. Shashikant Gawai and Mrs. Rama Devi for helping in confocal microscopy and Flow cytometry. Thanks to Dr. Jayant Hole for help in animal experiments. AK is supported by UGC fellowship and registered for Ph.D. program at RCB, Faridabad. VV is supported by CSIR fellowship and registered for Ph.D. program at Manipal University, Manipal.

\section{SUPPLEMENTARY MATERIAL}

The Supplementary Material for this article can be found online at: https://www.frontiersin.org/articles/10.3389/fimmu.2021.807775/ full\#supplementary-material

16. Brinkmann V, Reichard U, Goosmann C, Fauler B, Uhlemann Y, Weiss DS, et al. Neutrophil Extracellular Traps Kill Bacteria. Science (2004) 303:1532-5. doi: 10.1126/science.1092385

17. Vieira ML, Teixeira AF, Pidde G, Ching ATC, Tambourgi DV, Nascimento A, et al. Leptospira Interrogans Outer Membrane Protein LipL21 Is a Potent Inhibitor of Neutrophil Myeloperoxidase. Virulence (2018) 9:414-25. doi: 10.1080/21505594.2017.1407484

18. Fernandes LG, Siqueira GH, Teixeira AR, Silva LP, Figueredo JM, Cosate MR, et al. Leptospira Spp.: Novel Insights Into Host-Pathogen Interactions. Vet Immunol Immunopathol (2016) 176:50-7. doi: 10.1016/j.vetimm.2015.12.004

19. Fraga TR, Isaac L, Barbosa AS. Complement Evasion by Pathogenic Leptospira. Front Immunol (2016) 7:623. doi: 10.3389/fimmu.2016.00623

20. Chin VK, Basir R, Nordin SA, Abdullah M, Sekawi Z. Pathology and Host Immune Evasion During Human Leptospirosis: A Review. Int Microbiol (2020) 23:127-36. doi: 10.1007/s10123-019-00067-3

21. Chassin C, Picardeau M, Goujon JM, Bourhy P, Quellard N, Darche S, et al. TLR4- and TLR2-Mediated B Cell Responses Control the Clearance of the Bacterial Pathogen, Leptospira Interrogans. J Immunol (2009) 183:2669-77. doi: 10.4049/jimmunol.0900506

22. Wang H, Wu Y, Ojcius DM, Yang XF, Zhang C, Ding S, et al. Leptospiral Hemolysins Induce Proinflammatory Cytokines Through Toll-Like Receptor 2-and 4-Mediated JNK and NF-kappaB Signaling Pathways. PloS One (2012) 7:e42266. doi: 10.1371/journal.pone.0042266

23. Lo YY, Hsu SH, Ko YC, Hung CC, Chang MY, Hsu HH, et al. Essential Calcium-Binding Cluster of Leptospira LipL32 Protein for Inflammatory Responses Through the Toll-Like Receptor 2 Pathway. J Biol Chem (2013) 288:12335-44. doi: 10.1074/jbc.M112.418699

24. Faisal SM, Varma VP, Subathra M, Azam S, Sunkara AK, Akif M, et al. Leptospira Surface Adhesin (Lsa21) Induces Toll Like Receptor 2 and 4 Mediated Inflammatory Responses in Macrophages. Sci Rep (2016) 6:39530. doi: 10.1038/srep39530

25. Stevenson B, Choy HA, Pinne M, Rotondi ML, Miller MC, Demoll E, et al. Leptospira Interrogans Endostatin-Like Outer Membrane Proteins Bind Host Fibronectin, Laminin and Regulators of Complement. PloS One (2007) 2: e1188. doi: 10.1371/journal.pone.0001188

26. Castiblanco-Valencia MM, Fraga TR, Silva LB, Monaris D, Abreu PA, Strobel $\mathrm{S}$, et al. Leptospiral Immunoglobulin-Like Proteins Interact With Human Complement Regulators Factor H, FHL-1, FHR-1, and C4BP. J Infect Dis (2012) 205:995-1004. doi: 10.1093/infdis/jir875

27. Breda LC, Hsieh CL, Castiblanco Valencia MM, Da Silva LB, Barbosa AS, Blom AM, et al. Fine Mapping of the Interaction Between C4b-Binding Protein and Outer Membrane Proteins LigA and LigB of Pathogenic Leptospira Interrogans. PloS Negl Trop Dis (2015) 9:e0004192. doi: 10.1371/ journal.pntd.0004192 
28. Da Silva LB, Miragaia Ldos S, Breda LC, Abe CM, Schmidt MC, Moro AM, et al. Pathogenic Leptospira Species Acquire Factor $\mathrm{H}$ and Vitronectin via the Surface Protein LcpA. Infect Immun (2015) 83:888-97. doi: 10.1128/ IAI.02844-14

29. Castiblanco-Valencia MM, Fraga TR, Breda LC, Vasconcellos SA, Figueira CP, Picardeau M, et al. Acquisition of Negative Complement Regulators by the Saprophyte Leptospira Biflexa Expressing LigA or LigB Confers Enhanced Survival in Human Serum. Immunol Lett (2016) 173:61-8. doi: 10.1016/ j.imlet.2016.03.005

30. Siqueira GH, Atzingen MV, De Souza GO, Vasconcellos SA, Nascimento A. Leptospira Interrogans Lsa23 Protein Recruits Plasminogen, Factor $\mathrm{H}$ and C4BP From Normal Human Serum and Mediates C3b and C4b Degradation. Microbiology (Reading) (2016) 162:295-308. doi: 10.1099/mic.0.000217

31. Scharrig E, Carestia A, Ferrer MF, Cedola M, Pretre G, Drut R, et al. Neutrophil Extracellular Traps Are Involved in the Innate Immune Response to Infection With Leptospira. PloS Negl Trop Dis (2015) 9: e0003927. doi: 10.1371/journal.pntd.0003927

32. Matsunaga J, Barocchi MA, Croda J, Young TA, Sanchez Y, Siqueira I, et al. Pathogenic Leptospira Species Express Surface-Exposed Proteins Belonging to the Bacterial Immunoglobulin Superfamily. Mol Microbiol (2003) 49:929-45. doi: 10.1046/j.1365-2958.2003.03619.x

33. Mcbride AJ, Cerqueira GM, Suchard MA, Moreira AN, Zuerner RL, Reis MG, et al. Genetic Diversity of the Leptospiral Immunoglobulin-Like (Lig) Genes in Pathogenic Leptospira Spp. Infect Genet Evol (2009) 9:196-205. doi: 10.1016/j.meegid.2008.10.012

34. Choy HA, Kelley MM, Chen TL, Moller AK, Matsunaga J, Haake DA. Physiological Osmotic Induction of Leptospira Interrogans Adhesion: LigA and LigB Bind Extracellular Matrix Proteins and Fibrinogen. Infect Immun (2007) 75:2441-50. doi: 10.1128/IAI.01635-06

35. Lin YP, Mcdonough SP, Sharma Y, Chang YF. The Terminal Immunoglobulin-Like Repeats of LigA and LigB of Leptospira Enhance Their Binding to Gelatin Binding Domain of Fibronectin and Host Cells. PloS One (2010) 5:e11301. doi: 10.1371/journal.pone.0011301

36. Silva EF, Medeiros MA, Mcbride AJ, Matsunaga J, Esteves GS, Ramos JG, et al. The Terminal Portion of Leptospiral Immunoglobulin-Like Protein LigA Confers Protective Immunity Against Lethal Infection in the Hamster Model of Leptospirosis. Vaccine (2007) 25:6277-86. doi: 10.1016/ j.vaccine.2007.05.053

37. Faisal SM, Yan W, Chen CS, Palaniappan RU, Mcdonough SP, Chang YF. Evaluation of Protective Immunity of Leptospira Immunoglobulin Like Protein A (LigA) DNA Vaccine Against Challenge in Hamsters. Vaccine (2008) 26:277-87. doi: 10.1016/j.vaccine.2007.10.029

38. Faisal SM, Yan W, Mcdonough SP, Chang YF. Leptospira ImmunoglobulinLike Protein A Variable Region (LigAvar) Incorporated in Liposomes and PLGA Microspheres Produces a Robust Immune Response Correlating to Protective Immunity. Vaccine (2009) 27:378-87. doi: 10.1016/j.vaccine. 2008.10.089

39. Coutinho ML, Choy HA, Kelley MM, Matsunaga J, Babbitt JT, Lewis MS, et al. A LigA Three-Domain Region Protects Hamsters From Lethal Infection by Leptospira Interrogans. PloS Negl Trop Dis (2011) 5:e1422. doi: 10.1371/ journal.pntd.0001422

40. Lourdault K, Wang LC, Vieira A, Matsunaga J, Melo R, Lewis MS, et al. Oral Immunization With Escherichia Coli Expressing a Lipidated Form of LigA Protects Hamsters Against Challenge With Leptospira Interrogans Serovar Copenhageni. Infect Immun (2014) 82:893-902. doi: 10.1128/IAI.01533-13

41. Evangelista KV, Lourdault K, Matsunaga J, Haake DA. Immunoprotective Properties of Recombinant LigA and LigB in a Hamster Model of Acute Leptospirosis. PloS One (2017) 12:e0180004. doi: 10.1371/journal. pone. 0180004

42. Choy HA. Multiple Activities of LigB Potentiate Virulence of Leptospira Interrogans: Inhibition of Alternative and Classical Pathways of Complement. PloS One (2012) 7:e41566. doi: 10.1371/journal.pone.0041566

43. Castiblanco-Valencia MM, Fraga TR, Pagotto AH, Serrano SM, Abreu PA, Barbosa AS, et al. Plasmin Cleaves Fibrinogen and the Human Complement Proteins C3b and C5 in the Presence of Leptospira Interrogans Proteins: A New Role of LigA and LigB in Invasion and Complement Immune Evasion. Immunobiology (2016) 221:679-89. doi: 10.1016/j.imbio.2016.01.001
44. Bunikis J, Barbour AG. Access of Antibody or Trypsin to an Integral Outer Membrane Protein (P66) of Borrelia Burgdorferi Is Hindered by Osp Lipoproteins. Infect Immun (1999) 67:2874-83. doi: 10.1128/IAI.67.6.28742883.1999

45. Barbour AG, Restrepo BI. Antigenic Variation in Vector-Borne Pathogens. Emerg Infect Dis (2000) 6:449-57. doi: 10.3201/eid0605.000502

46. Xu Q, Seemanapalli SV, Mcshan K, Liang FT. Constitutive Expression of Outer Surface Protein C Diminishes the Ability of Borrelia Burgdorferi to Evade Specific Humoral Immunity. Infect Immun (2006) 74:5177-84. doi: 10.1128/IAI.00713-06

47. Matsuura M. Structural Modifications of Bacterial Lipopolysaccharide That Facilitate Gram-Negative Bacteria Evasion of Host Innate Immunity. Front Immunol (2013) 4:109. doi: 10.3389/fimmu.2013.00109

48. Viriyakosol S, Matthias MA, Swancutt MA, Kirkland TN, Vinetz JM. TollLike Receptor 4 Protects Against Lethal Leptospira Interrogans Serovar Icterohaemorrhagiae Infection and Contributes to In Vivo Control of Leptospiral Burden. Infect Immun (2006) 74:887-95. doi: 10.1128/ IAI.74.2.887-895.2006

49. Hung CC, Chang CT, Tian YC, Wu MS, Yu CC, Pan MJ, et al. Leptospiral Membrane Proteins Stimulate Pro-Inflammatory Chemokines Secretion by Renal Tubule Epithelial Cells Through Toll-Like Receptor 2 and P38 Mitogen Activated Protein Kinase. Nephrol Dial Transplant (2006) 21:898-910. doi: 10.1093/ndt/gfi316

50. Yang CW. Leptospirosis Renal Disease: Understanding the Initiation by TollLike Receptors. Kidney Int (2007) 72:918-25. doi: 10.1038/sj.ki.5002393

51. Zhang Y, Bao L, Zhu H, Huang B, Zhang H. OmpA-Like Protein Loa22 From Leptospira Interrogans Serovar Lai Is Cytotoxic to Cultured Rat Renal Cells and Promotes Inflammatory Responses. Acta Biochim Biophys Sin (Shanghai) (2010) 42:70-9. doi: 10.1093/abbs/gmp109

52. Matsunaga J, Lo M, Bulach DM, Zuerner RL, Adler B, Haake DA. Response of Leptospira Interrogans to Physiologic Osmolarity: Relevance in Signaling the Environment-to-Host Transition. Infect Immun (2007) 75:2864-74. doi: 10.1128/IAI.01619-06

53. Ogawa T, Asai Y, Hashimoto M, Uchida H. Bacterial Fimbriae Activate Human Peripheral Blood Monocytes Utilizing TLR2, CD14 and CD11a/CD18 as Cellular Receptors. Eur J Immunol (2002) 32:2543-50. doi: 10.1002/15214141(200209)32:9<2543::AID-IMMU2543>3.0.CO;2-2

54. Hajishengallis G, Ratti P, Harokopakis E. Peptide Mapping of Bacterial Fimbrial Epitopes Interacting With Pattern Recognition Receptors. J Biol Chem (2005) 280:38902-13. doi: 10.1074/jbc.M507326200

55. Sing A, Reithmeier-Rost D, Granfors K, Hill J, Roggenkamp A, Heesemann J. A Hypervariable N-Terminal Region of Yersinia LcrV Determines Toll-Like Receptor 2-Mediated IL-10 Induction and Mouse Virulence. Proc Natl Acad Sci USA (2005) 102:16049-54. doi: 10.1073/pnas.0504728102

56. Chambers MA, Whelan AO, Spallek R, Singh M, Coddeville B, Guerardel Y, et al. Non-Acylated Mycobacterium Bovis Glycoprotein MPB83 Binds to TLR1/2 and Stimulates Production of Matrix Metalloproteinase 9. Biochem Biophys Res Commun (2010) 400:403-8. doi: 10.1016/j.bbrc.2010.08.085

57. Liu X, Wetzler LM, Nascimento LO, Massari P. Human Airway Epithelial Cell Responses to Neisseria Lactamica and Purified Porin via Toll-Like Receptor 2Dependent Signaling. Infect Immun (2010) 78:5314-23. doi: 10.1128/ IAI.00681-10

58. Byun EH, Kim WS, Shin AR, Kim JS, Whang J, Won CJ, et al. Rv0315, A Novel Immunostimulatory Antigen of Mycobacterium Tuberculosis, Activates Dendritic Cells and Drives Th1 Immune Responses. J Mol Med (Berl) (2012) 90:285-98. doi: 10.1007/s00109-011-0819-2

59. Choi HG, Choi S, Back YW, Park HS, Bae HS, Choi CH, et al. Mycobacterium Tuberculosis Rv2882c Protein Induces Activation of Macrophages Through TLR4 and Exhibits Vaccine Potential. PloS One (2016) 11:e0164458. doi: 10.1371/journal.pone.0164458

60. Berguer PM, Mundinano J, Piazzon I, Goldbaum FA. A Polymeric Bacterial Protein Activates Dendritic Cells via TLR4. J Immunol (2006) 176:2366-72. doi: 10.4049/jimmunol.176.4.2366

61. Pasquevich KA, Garcia Samartino C, Coria LM, Estein SM, Zwerdling A, Ibanez AE, et al. The Protein Moiety of Brucella Abortus Outer Membrane Protein 16 Is a New Bacterial Pathogen-Associated Molecular Pattern That Activates Dendritic Cells In Vivo, Induces a Th1 Immune Response, and Is a 
Promising Self-Adjuvanting Vaccine Against Systemic and Oral Acquired Brucellosis. J Immunol (2010) 184:5200-12. doi: 10.4049/jimmunol.0902209

62. Li JY, Liu Y, Gao XX, Gao X, Cai H. TLR2 and TLR4 Signaling Pathways Are Required for Recombinant Brucella Abortus BCSP31-Induced Cytokine Production, Functional Upregulation of Mouse Macrophages, and the Th1 Immune Response In Vivo and In Vitro. Cell Mol Immunol (2014) 11:477-94. doi: $10.1038 / \mathrm{cmi} .2014 .28$

63. Jung SB, Yang CS, Lee JS, Shin AR, Jung SS, Son JW, et al. The Mycobacterial 38-Kilodalton Glycolipoprotein Antigen Activates the Mitogen-Activated Protein Kinase Pathway and Release of Proinflammatory Cytokines Through Toll-Like Receptors 2 and 4 in Human Monocytes. Infect Immun (2006) 74:2686-96. doi: 10.1128/IAI.74.5.2686-2696.2006

64. Chen ST, Li JY, Zhang Y, Gao X, Cai H. Recombinant MPT83 Derived From Mycobacterium Tuberculosis Induces Cytokine Production and Upregulates the Function of Mouse Macrophages Through TLR2. J Immunol (2012) 188:668-77. doi: 10.4049/jimmunol.1102177

65. Sjolinder M, Altenbacher G, Wang X, Gao Y, Hansson C, Sjolinder H. The Meningococcal Adhesin NhhA Provokes Proinflammatory Responses in Macrophages via Toll-Like Receptor 4-Dependent and -Independent Pathways. Infect Immun (2012) 80:4027-33. doi: 10.1128/IAI.00456-12

66. Lee SJ, Shin SJ, Lee MH, Lee MG, Kang TH, Park WS, et al. A Potential Protein Adjuvant Derived From Mycobacterium Tuberculosis Rv0652 Enhances Dendritic Cells-Based Tumor Immunotherapy. PloS One (2014) 9:e104351. doi: 10.1371/journal.pone.0104351

67. Bao Y, Liu X, Han C, Xu S, Xie B, Zhang Q, et al. Identification of IFNGamma-Producing Innate B Cells. Cell Res (2014) 24:161-76. doi: 10.1038/ cr.2013.155

68. Johnson RC, Muschel LH. Antileptospiral Activity of Normal Serum. J Bacteriol (1965) 89:1625-6. doi: 10.1128/jb.89.6.1625-1626.1965

69. Meri T, Murgia R, Stefanel P, Meri S, Cinco M. Regulation of Complement Activation at the C3-Level by Serum Resistant Leptospires. Microb Pathog (2005) 39:139-47. doi: 10.1016/j.micpath.2005.07.003

70. Verma A, Hellwage J, Artiushin S, Zipfel PF, Kraiczy P, Timoney JF, et al. LfhA, a Novel Factor H-Binding Protein of Leptospira Interrogans. Infect Immun (2006) 74:2659-66. doi: 10.1128/IAI.74.5.2659-2666.2006

71. Barbosa AS, Monaris D, Silva LB, Morais ZM, Vasconcellos SA, Cianciarullo AM, et al. Functional Characterization of LcpA, a Surface-Exposed Protein of Leptospira Spp. That Binds the Human Complement Regulator C4BP. Infect Immun (2010) 78:3207-16. doi: 10.1128/IAI.00279-10

72. Souza NM, Vieira ML, Alves IJ, De Morais ZM, Vasconcellos SA, Nascimento AL. Lsa30, A Novel Adhesin of Leptospira Interrogans Binds Human Plasminogen and the Complement Regulator C4bp. Microb Pathog (2012) 53:125-34. doi: 10.1016/j.micpath.2012.06.001

73. Wolff DG, Castiblanco-Valencia MM, Abe CM, Monaris D, Morais ZM, Souza GO, et al. Interaction of Leptospira Elongation Factor Tu With Plasminogen and Complement Factor H: A Metabolic Leptospiral Protein
With Moonlighting Activities. PloS One (2013) 8:e81818. doi: 10.1371/ journal.pone. 0081818

74. Kochi LT, Fernandes LGV, Souza GO, Vasconcellos SA, Heinemann MB, Romero EC, et al. The Interaction of Two Novel Putative Proteins of Leptospira Interrogans With E-Cadherin, Plasminogen and Complement Components With Potential Role in Bacterial Infection. Virulence (2019) 10:734-53. doi: 10.1080/21505594.2019.1650613

75. Mcdonald B, Urrutia R, Yipp BG, Jenne CN, Kubes P. Intravascular Neutrophil Extracellular Traps Capture Bacteria From the Bloodstream During Sepsis. Cell Host Microbe (2012) 12:324-33. doi: 10.1016/j.chom.2012.06.011

76. Berends ET, Horswill AR, Haste NM, Monestier M, Nizet V, Von KockritzBlickwede M. Nuclease Expression by Staphylococcus Aureus Facilitates Escape From Neutrophil Extracellular Traps. J Innate Immun (2010) 2:57686. doi: 10.1159/000319909

77. Zheng L, Khemlani A, Lorenz N, Loh JM, Langley RJ, Proft T. Streptococcal 5'-Nucleotidase A (S5nA), a Novel Streptococcus Pyogenes Virulence Factor That Facilitates Immune Evasion. J Biol Chem (2015) 290:31126-37. doi: 10.1074/jbc.M115.677443

78. Jhelum H, Sori H, Sehgal D. A Novel Extracellular Vesicle-Associated Endodeoxyribonuclease Helps Streptococcus Pneumoniae Evade Neutrophil Extracellular Traps and Is Required for Full Virulence. Sci Rep (2018) 8:7985. doi: 10.1038/s41598-018-25865-z

79. Kumar S, Sunagar R, Gosselin E. Bacterial Protein Toll-Like-Receptor Agonists: A Novel Perspective on Vaccine Adjuvants. Front Immunol (2019) 10:1144. doi: 10.3389/fimmu.2019.01144

80. Swamydas M, Lionakis MS. Isolation, Purification and Labeling of Mouse Bone Marrow Neutrophils for Functional Studies and Adoptive Transfer Experiments. J Vis Exp (2013) 10(77):e50586. doi: 10.3791/50586

Conflict of Interest: The authors declare that the research was conducted in the absence of any commercial or financial relationships that could be construed as a potential conflict of interest.

Publisher's Note: All claims expressed in this article are solely those of the authors and do not necessarily represent those of their affiliated organizations, or those of the publisher, the editors and the reviewers. Any product that may be evaluated in this article, or claim that may be made by its manufacturer, is not guaranteed or endorsed by the publisher.

Copyright (c) 2021 Kumar, Varma, Sridhar, Abdullah, Vyas, Ashiq Thalappil, Chang and Faisal. This is an open-access article distributed under the terms of the Creative Commons Attribution License (CC BY). The use, distribution or reproduction in other forums is permitted, provided the original author(s) and the copyright owner(s) are credited and that the original publication in this journal is cited, in accordance with accepted academic practice. No use, distribution or reproduction is permitted which does not comply with these terms. 